\title{
Chemical and boron isotopic compositions of tourmaline at the Dachang Sn-polymetallic ore district in South China: Constraints on the origin and evolution of hydrothermal fluids
}

Kui-Dong Zhao ${ }^{1}$, Ling-Huo Zhang ${ }^{1}$, Martin R. Palmer ${ }^{2}$, Shao-Yong Jiang ${ }^{1}$, Cong Xu ${ }^{1}$, HeDong Zhao ${ }^{1}$, Wei Chen ${ }^{1}$

1. State Key Laboratory of Geological Processes and Mineral Resources, Collaborative, Innovation Center for Exploration of Strategic Mineral Resources, School of Earth, Resources, China University of Geosciences, Wuhan 430074, People’s Republic of China

2. National Oceanography Centre, School of Ocean and Earth Science, University of Southampton, Southampton SO14 3ZH, UK

\begin{abstract}
The Dachang Sn-polymetallic ore district in South China is the second largest tin district in the world with a tin reserve of over one million tonnes. Zn-Cu skarn and stratiform, massive, and vein $\mathrm{Sn}-\mathrm{Pb}-\mathrm{Zn}$ ores are all present in this district. This has led to a debate as to whether the $\mathrm{Sn}$ orebodies were formed by Cretaceous magmatic-hydrothermal replacement or Devonian submarine exhalative-hydrothermal sedimentation. Here, we present a systematic investigation of the major, trace element, and boron isotopic compositions of different types of tourmaline in the Dachang ore district. Tourmaline disseminated in the Longxianggai granite and pegmatite veins belongs to the schorl series and has high contents of $\mathrm{Li}, \mathrm{Zn}$, and Ga. The $\delta^{11} \mathrm{~B}$ value of primary magma of the Longxianggai granite is estimated to be about $-13 \%$, close to the global average $\delta^{11} \mathrm{~B}$ value (-11\%) for S-type granites. Tourmaline from quartz-tourmaline veins in the Longxianggai granite has similar chemical composition to the magmatic
\end{abstract}


tourmaline and likely formed from hydrothermal fluids exsolved from the evolved granitic melt. The $\delta^{11} \mathrm{~B}$ value of the initial hydrothermal fluids is also calculated to be about $-13 \%$. Tourmalines from the skarn and sulfide ores in the Lamo deposit have higher $\mathrm{Mg} /(\mathrm{Mg}+\mathrm{Fe})$ and lower $\mathrm{Na} /(\mathrm{Na}+\mathrm{Ca})$ ratios and higher contents of $\mathrm{Be}, \mathrm{Ge}, \mathrm{Sr}$, and $\mathrm{Sn}$ than magmatic tourmaline. These patterns likely reflect input of elements derived from the host Devonian limestone. The $\delta^{11} \mathrm{~B}$ values of the hydrothermal fluidsre estimated to be between -13 and $-10 \%$, suggesting evolved magmatic-hydrothermal fluids related to the Longxianggai granite. Tourmalines from the stratiform and vein ores in the Changpo-Tongkeng deposit are extremely Mg-rich and mostly belong to the dravite series. They have high contents of Sc, V, Cr, Sr, and Sn and show positive Eu anomalies. The $\delta^{11} \mathrm{~B}$ values of these $\mathrm{B}$ - and Sn-rich fluids are estimated to be between -15 and $-10 \%$, suggesting that the fluids also have a magmatic hydrothermal origin. These fluids are most likely derived from the same granitic magma source, but may have interacted with the Devonian volcanic rocks.

\section{Introduction}

Most primary tin deposits in the world are spatially associated with differentiated granites and are interpreted to be of magmatic-hydrothermal origin (Lehmann 1990; Heinrich 1990), but some strata-bound deposits hosted by sedimentary and volcanic rocks also produced byproduct tin, e.g., Geco (Petersen 1986) and Kidd Creek (Hennigh and Hutchinson 1999) in Canada, Neves Corvo (Relvas et al. 2001; Li et al. 2019) in Portugal, and Gejiu (Mao et al. 2008) and Dachang in China. The Dachang Sn-polymetallic ore district is located in Nandan County in Guangxi Zhuang Autonomous Region, South China (Fig. 1). It is also an important producing area for $\mathrm{Zn}, \mathrm{Pb}, \mathrm{Cu}, \mathrm{Ag}$, Sb, In, and $\mathrm{Cd}$. Several ore types exist within the Dachang ore district including the following: (1) the Zn-Cu skarn ores at the contact zone between Cretaceous Longxianggai granite and Devonian limestone in the Lamo deposit, (2) the 
stratiform and vein Sn-Pb-Zn ores hosted by Upper Devonian siliceous rocks and limestone in the Changpo-Tongkeng deposit, and (3) the massive Sn-Pb-Zn ores hosted by Middle Devonian reef limestone in the Gaofeng deposit. The skarn ores at the Lamo deposit have a granitic magmatic hydrothermal origin (Fu et al. 1991; Chen et al. 1993). Conversely, there is a dispute as to whether the stratiform and massive ores are of Cretaceous magmatic-hydrothermal replacement origin (Fu et al. 1991, 1993; Chen et al. 1993; Cai et al. 2007; Liang et al. 2008) or Devonian submarine exhalative-hydrothermal sedimentary origin (SEDEX) (Han et al. 1997; Jiang et al. 1999; Zhao et al. 2002, 2007; Zhao and Jiang 2007). Recently, Guo et al. (2018) reported U-Pb ages of cassiterite from different deposits at Dachang, indicating that tin mineralization ages range from 90 to $95 \mathrm{Ma}$ and are identical to the emplacement age of the Longxianggai granite (91-97 Ma, Cai et al. 2006; Liang et al. 2011). Thus, tin mineralization at the Dachang district likely formed from a magmatic-hydrothermal system related to the Longxianggai granite (Guo et al. 2018). However, uncertainty remains concerning the evolution of hydrothermal fluids in the different types of mineralization.

Tourmaline is an important gangue mineral in many hydrothermal ore deposits, especially in massive sulfide deposits and granite-related Sn-W deposits (Slack 1996). Hence, tourmaline in different types of ore deposits has been a topic of many chemical and isotopic investigations (Mao 1995; Jiang et al. 1998, 2002; Slack and Trumbull 2011; Mercadier et al. 2012; Lambert-Smithm et al. 2016; Su et al. 2016, 2019; Adlakha et al. 2017; Codeço et al. 2017; Duchoslav et al. 2017; Kalliomäki et al. 2017; Ranta et al. 2017; Albert et al. 2018; Trumbull et al. 2019; Harlaux et al. 2019, 2020; Sciuba et al. 2020). Previous studies showed that tourmaline can provide important information about the mineralization environment and ore genesis of the associated deposits. Tourmaline is also present throughout the Dachang ore district and is especially widespread in the stratiform orebodies in the Changpo-Tongkeng deposit. Jiang et al. (1999) analyzed the trace element and Sr-Nd isotopic compositions of 
tourmaline from both the stratiform orebodies at Changpo-Tongkeng and granite-related hydrothermal veins at Lamo. The two types of tourmaline show different geochemical characteristics and likely formed from different types of fluids, with Mg-rich tourmaline in the stratiform orebodies suggested to be of submarine exhalative-hydrothermal origin. Jiang (2001) reported twelve boron isotopic compositions of tourmaline from the Dachang district, with $\delta^{11} \mathrm{~B}$ values between -17.5 and $-14.5 \%$. These analyses were performed on bulk mineral grains. In this study, we carried out in situ major, trace element, and B isotopic analyses of tourmaline from various types of ore in the Dachang district. These new data provide more detailed information concerning the origin and evolution of the hydrothermal fluids.

\section{Geologic setting and geology of ore deposits}

The Youjiang Basin is a Devonian-Triassic basin developed on the southwestern margin of South China, at the junction of the Yangtze, the Cathaysia, and the Indochina blocks (Fig. 1a). A series of world-class Sn-polymetallic ore districts are distributed in the Youjiang Basin, including the Gejiu, Bainiuchang, Dulong, Mangchang, Dachang, and Wuxu (Fig. 1b). The Dachang Sn-polymetallic ore district is located in the middle of the Danchi (Nandan-Hechi) Trough, which flanks the northeast margin of the Youjiang Basin and is adjacent to the Jiangnan Fold Belt (Fig. 2). The Jiangnan Fold Belt formed during the amalgamation of the Cathaysian and Yangtze Blocks in the Neoproterozoic ( $\mathrm{Li}$ et al. 2009). The metamorphic basement in this region comprises Neoproterozoic greenschist facies, flysch turbidite, and Cambrian sandstone and calcareous shale.

The sedimentary rocks (with maximal thickness of $\sim 4000 \mathrm{~m}$ ) in the Dachang district range from Lower Devonian to Tertiary; among them, the Middle-Upper Devonian strata host most of the economic mineralization. The Middle Devonian rocks include black shales and limestone developed in the Danchi Trough and a shallow-water carbonate reef developed on 
the marginal platform (Fig. 3 and Fig. 4). The Upper Devonian rocks are typical intraplatform trough sediments, composed mainly of thick- to thin-layered massive, laminated, and banded chert, limestone, and siliceous black shales (Fan et al. 2004). Some basalt-andesite volcanic intercalations have been found in the Devonian strata (Liu et al. 2012).

The Longxianggai granite is the largest intrusive body in the Dachang district with an outcrop area of only $0.5 \mathrm{~km}^{2}$ at Lamo (Fig. 3). The age of the granite is constrained by zircon U-Pb ages of 91 97 Ma (Cai et al. 2006; Liang et al. 2011). The granite is mainly equigranular biotite granite, composed of quartz ( 30 vol.\%), K-feldspar ( 35 vol.\%), plagioclase ( 25 vol.\%), and biotite ( 5 vol.\%), and has been classified as peraluminous S-type granite (Chen et al. 1993). North-South-trending granite porphyry and diorite porphyry dykes occur in the west of the ore district (Fig. 3) and crosscut the tin-dominant polymetallic orebodies at Changpo-Tongkeng and Gaofeng. The granite porphyry has a fine-grained matrix, with phenocrysts of quartz and K-feldspar. The diorite porphyry is characterized by plagioclase, quartz, K-feldspar, and biotite as phenocrysts occurring in a micro- to fine-grained matrix. The granite porphyry and diorite porphyry were emplaced at $91 \mathrm{Ma}$, as determined by zircon U-Pb ages (Cai et al. 2006). Some small pegmatite veins and segregations, with widths of several to tens of centimeters, occur in the marginal phase of the Longxianggai granite. These pegmatitic segregations are scarce and consist largely of quartz, feldspar, and tourmaline mega-crystals.

The Dachang district contains several deposits, including the Lamo $\mathrm{Zn}-\mathrm{Cu}$, the Changpo-Tongkeng Sn-Pb-Zn, and the Gaofeng Sn-Pb-Zn deposits (Fig. 3 and Table 1). Some small Sn-polymetallic mineralized veins also occur in the eastern part of the district (e.g., the Dafulou, Huile, and Kangma deposits). A vein antimony ore deposit (Chashan) is located in the center of the district.

The Lamo deposit consists of mainly skarn orebodies, which occur at the contact zone between the Upper Devonian limestone and the Longxianggai granite (Fig. 5). The deposit 
contains $10 \mathrm{Mt}$ of ore with grades of $2 \% \mathrm{Cu}$ and $5 \% \mathrm{Zn}$, whereas the Sn grade is usually < 0.1\% (Han et al. 1997). The orebodies at Lamo occur as chimneys, mantos, and pods in the skarn. The skarn minerals include garnet, wollastonite, diopside, tremolite, vesuvianite, actinolite, fluorite, and epidote. Sulfides occur as disseminated aggregates in aluminosilicate minerals and veinlets crosscutting the early skarn. The ore minerals are mainly sphalerite, chalcopyrite, pyrrhotite, and arsenopyrite.

The Changpo-Tongkeng deposit is located $\sim 5 \mathrm{~km}$ southwest of the Longxianggai granite and is the largest Sn-polymetallic deposit in the Dachang ore district. The deposit includes upper vein orebodies and lower stratiform orebodies (Fig. 5). The No. 91 and No. 92 orebodies are two of the largest stratiform orebodies and are hosted within the Upper Devonian banded siliceous rocks and limestone (Fig. 4). The No. 91 orebody is mainly hosted by banded limestone and contains $~ 50 \mathrm{Mt}$ of ore at 1.3\% Sn and 4.0\% Zn (Han et al. 1997). The underlying No. 92 orebody is mainly hosted by siliceous rocks and contains 25 Mt of ore at $0.8 \%$ Sn and 2.1\% Zn (Han et al. 1997). The stratiform orebodies are mainly composed of bedded, laminated, and lenticular ores. In the bedded and laminated ores, the fine-banded siliceous rocks, limestones, tourmalinites, and K-feldspar-rich rocks are interbedded with sulfidecassiterite beds. The ore minerals include cassiterite, sphalerite, arsenopyrite, pyrite, and jamesonite. The gangue minerals are quartz, calcite, tourmaline, and sericite. Vein and stockwork orebodies occur in the upper part of the deposit (Fig. 5) and contain 10 Mt ore at 1.0\% Sn and 4\% Zn (Han et al. 1997). Despite variations in sulphide abundance and mineral grain size, both the stratiform and vein ores have similar mineral assemblages.

The Gaofeng deposit is mainly composed of the No. 100 orebody, which occurs as a dome-like lens hosted by the Middle Devonian reef limestone (Fig. 4). The orebody is composed of massive sulfides and cassiterite. It contains 10 Mt of high-grade ore averaging 1.86\% Sn, 9.7\% Zn, 4.8\% Pb, 4.2\% Sb, and 148 g/t Ag (Han et al. 1997). The ore minerals 
mainly comprise cassiterite, pyrrhotite, pyrite, boulangerite, and marcasite. The gangue minerals predominantly consist of quartz and calcite.

\section{Tourmaline occurrences and sampling strategy}

Tourmaline is abundant in the Dachang ore district, with three main types of occurrences identified from field and detailed petrographic observations: (1) in the granite and pegmatite, (2) in skarn orebodies of the Lamo deposit, and (3) in stratiform and vein orebodies of the Changpo-Tongkeng deposit.We did not find tourmaline in the Gaofeng massive sulfide orebodies.

Tourmaline in the magmatic rocks

Tourmaline in the Longxianggai granite samples (16DC-95, 16DC-97) is disseminated throughout the medium-grained biotite granite (Tur-M1). It is generally euhedral to subhedral and tens to several hundred micrometers in size (Fig. 6a-b). The tourmaline crystals are generally intergrown with quartz and plagioclase and exhibit slight pleochroism from light yellow to blue without optical zoning. The plagioclase shows a certain degree of hydrothermal alteration. On backscattered electron (BSE) images, the tourmaline crystals show a relatively homogeneous texture and do not display internal zoning.

Tourmaline is abundant in the pegmatite veins (Tur-M2; samples 16DC-101, 16DC102, 16DC-103) and the crystals are euhedral and columnar, up to several centimeters in length (Fig. 6c). The tourmaline is generally intergrown with quartz and plagioclase (Fig. 6d). The tourmaline crystals generally exhibit slight light yellow pleochroism without optical zoning. On BSE images, the tourmaline crystals do not show internal zoning.

Tourmaline-quartz veins are also present in the Longxianggai granite (Tur-M3; samples 16DC-149, 16DC 150) (Fig. 6e) as subhedral crystal aggregates of up to several millimeters in size. The tourmaline is generally intergrown with quartz and exhibits slight light blue 
pleochroism (Fig. 6f). On BSE images, the tourmaline crystals display light gray cores and oscillatory-zoned rims.

\section{Tourmaline in the Lamo deposit}

Tourmaline commonly occurs as disseminated grains in the Lamo orebodies. For example, a garnet skarn sample (16DC-106) contains fine-grained euhedral tourmaline crystals (Tur-L1; Fig. 7a-b) in association with garnet, diopside, tremolite, and fluorite, suggesting they formed at the retrograde skarn stage. The tourmaline forms euhedral columnar crystals of tens to several hundred micrometers in length and generally exhibits slight blue pleochroism.

Sulfide ore samples (16DC-104, 16DC-105, 16DC-112, 16DC-121) from the Lamo deposit contain disseminated tourmaline crystals (Tur-L2) in the form of euhedral acicular crystals of up several millimeters in length (Fig. 7c-d). The tourmaline is generally intergrown with arsenopyrite, fluorite, and quartz and locally contains cassiterite, fluorite, and apatite (Fig. 7e), suggesting they are produced from syn-mineralization. In backscattered electron (BSE) images, the tourmaline displays well-defined oscillatory-zoned textures (Fig. 7f).

\section{Tourmaline in the Changpo-Tongkeng deposit}

Tourmaline occurs as fine grains in both the stratiform and vein ores in the Changpo-Tongkeng deposit. In the bedded ore samples (T-31, T-42, T-45a, T-57, 16DC-33, 16DC-36, 16DC-40, 16DC-45) from the No. 91 and No. 92 orebodies, tourmaline (Tur-C1) occurs as euhedral columnar crystals intergrown with the sphalerite (Fig. 8a-b). The tourmaline crystals are small, generally $10-30 \mu \mathrm{m}$ in width and $50-200 \mu \mathrm{m}$ in length. On BSE images, they do not show internal zoning (Fig. 8c-d).

In the sulfide vein ore samples (T-51a, T-51b, T-55) from the upper vein-type orebodies at the Changpo-Tongkeng deposit, tourmaline (Tur-C2) occurs as euhedral columnar crystals intergrown with pyrite (Fig. 8e-f).The tourmaline crystals are also small, generally 10-20 $\mu \mathrm{m}$ in width and 50-200 $\mu \mathrm{m}$ in length (Fig. 8f). 


\section{Analytical methods}

Major element compositions of tourmaline were determined by a JEOL JXA-8100 Electron Probe Micro Analyzer (EPMA) at the State Key Laboratory of Geological Processes and Mineral Resources (GPMR) in China University of Geosciences, Wuhan. An accelerating voltage of $15 \mathrm{kV}$, a beam current of $20 \mathrm{nA}$, and a beam diameter of $5 \mu \mathrm{m}$ were used during the analyses. The peak counting times were $10 \mathrm{~s}$ for $\mathrm{Na}, \mathrm{Mg}, \mathrm{Al}, \mathrm{Si}, \mathrm{K}$, and $\mathrm{Fe}$ and $20 \mathrm{~s}$ for Ti,Mn, Ca, F, andCl. The following standards were used: sanidine (K), pyrope garnet (Fe, $\mathrm{Al}$ ), diopside (Ca, Mg), jadeite ( $\mathrm{Na})$, rhodonite (Mn), olivine ( $\mathrm{Si})$, rutile (Ti), topaz (F), and halite (Cl). Data were corrected online using a modified ZAF correction procedure. Tourmaline structural formulae were calculated by normalizing to 15 cations in the octahedral and tetrahedral $(\mathrm{T}+\mathrm{Z}+\mathrm{Y})$ site and assuming $\mathrm{B}=3$ atoms per formula unit (apfu) and by using the Excel program provided by Morgan (2016).

In situ major and trace element analyses of tourmaline were obtained directly on polished thin sections using a RESOlution S-155 laser ablation system coupled to a Thermo iCAP Qc inductively coupled plasma mass spectrometer (LA-ICP-MS) at GPMR. NIST SRM 612 and 610 glass standards (Jochum et al. 2011) and the USGS reference glasses (BIR-1G, BCR-2G, and BHVO-2G) (Jochum et al. 2005) were analyzed between every 7-10 tourmaline samples. Both standards and samples were ablated using a $50 \mu \mathrm{m}$ spot size, $10 \mathrm{~Hz}$ repetition rate, and $\sim 4 \mathrm{~J} / \mathrm{cm}^{2}$ corresponding energy density. Helium gas ( $\left.\sim 400 \mathrm{ml} / \mathrm{min}\right)$ carrying the ablated sample aerosol was mixed with argon gas $(\sim 800 \mathrm{ml} / \mathrm{min})$ and a small amount of nitrogen gas ( $4 \mathrm{ml} / \mathrm{min})$ as an additional diatomic gas to enhance sensitivity, before flowing into the ICPMS. The following 55 isotopes were measured with a dwell time of $10 \mathrm{~ms}$ for each: ${ }^{7} \mathrm{Li},{ }^{9} \mathrm{Be},{ }^{11} \mathrm{~B},{ }^{23} \mathrm{Na},{ }^{25} \mathrm{Mg},{ }^{27} \mathrm{Al},{ }^{29} \mathrm{Si},{ }^{31} \mathrm{P},{ }^{39} \mathrm{~K},{ }^{42} \mathrm{Ca},{ }^{45} \mathrm{Sc},{ }^{47} \mathrm{Ti},{ }^{51} \mathrm{~V},{ }^{53} \mathrm{Cr},{ }^{55} \mathrm{Mn},{ }^{57} \mathrm{Fe},{ }^{59} \mathrm{Co},{ }^{60} \mathrm{Ni}$, ${ }^{63} \mathrm{Cu},{ }^{66} \mathrm{Zn},{ }^{71} \mathrm{Ga},{ }^{73} \mathrm{Ge},{ }^{85} \mathrm{Rb},{ }^{88} \mathrm{Sr},{ }^{89} \mathrm{Y},{ }^{90} \mathrm{Zr},{ }^{93} \mathrm{Nb},{ }^{95} \mathrm{Mo},{ }^{111} \mathrm{Cd},{ }^{115} \mathrm{In},{ }^{118} \mathrm{Sn},{ }^{121} \mathrm{Sb},{ }^{133} \mathrm{Cs},{ }^{137} \mathrm{Ba}$, 
${ }^{139} \mathrm{La},{ }^{140} \mathrm{Ce},{ }^{141} \mathrm{Pr},{ }^{146} \mathrm{Nd},{ }^{147} \mathrm{Sm},{ }^{153} \mathrm{Eu},{ }^{157} \mathrm{Gd},{ }^{159} \mathrm{~Tb},{ }^{163} \mathrm{Dy},{ }^{165} \mathrm{Ho},{ }^{166} \mathrm{Er},{ }^{169} \mathrm{Tm},{ }^{173} \mathrm{Yb},{ }^{175} \mathrm{Lu}$, ${ }^{178} \mathrm{Hf},{ }^{181} \mathrm{Ta},{ }^{182} \mathrm{~W},{ }^{208} \mathrm{~Pb},{ }^{209} \mathrm{Bi},{ }^{232} \mathrm{Th}$, and ${ }^{238} \mathrm{U}$. The cycle time was about $600 \mathrm{~ms}$. External calibrations were performed using the above USGS reference glasses. The NIST glasses were used for correcting the signal drift. The isotope ${ }^{29} \mathrm{Si}$ was used as the internal standard in conjunction with the Si concentrations determined previously by EPMA. Raw data reduction was performed offline using the ICPMSDataCal software (Liu et al. 2010). The variation ranges of major elements are identical to those acquired by the EPMA method for the same samples. The analytical precisions for most elements are estimated to be better than $10 \%$ based on analyses of MPDing reference glasses.

Boron isotopic compositions of tourmaline were measured using the same laser ablation system coupled to a Nu plasma II multi-collector ICP-MS (LA-MC-ICP-MS). Analyses were carried out with a $50 \mu \mathrm{m}$ beam diameter and $10 \mathrm{~Hz}$ repetition rate. ${ }^{11} \mathrm{~B}$ and ${ }^{10} \mathrm{~B}$ signals were collected statically and simultaneously by two Faraday cups. The instrumental mass fractionation was calibrated using the standard-sample-standard bracketing method using the international tourmaline standard IAEA B4 $\left(\delta^{11} \mathrm{~B}=-8.71 \%\right.$, Tonarini et al. 2003) as the external standard. Analytical quality was assessed by replicate analyses of tourmaline reference materials dravite (HS\#108796) and schorl (HS\#112566) from the Harvard Mineralogical Museum (Dyar et al. 2001). The external precision $(2 \sigma)$ is estimated to be better than $0.5 \%$ based on replicate analyses of reference tourmalines during this study. The internal precision (1SD) in per mil for single analysis is calculated from about 100 cycles during each analysis.

\section{Results}

Tourmaline classification and major element variations

The chemical compositions obtained by EPMA and LA-ICPMS and structural formulae are given in Electronic Supplementary Materials (ESM Table S1). Tourmaline structural formula 
depends on relative occupancies of major elements in crystallographic sites described by $\mathrm{XY}_{3} \mathrm{Z}_{6}\left(\mathrm{~T}_{6} \mathrm{O}_{18}\right)\left(\mathrm{BO}_{3}\right) \mathrm{V}_{3} \mathrm{~W}$ (Henry et al. 2011). Variations of greatest petrologic interest occur on the X-site $\left(\mathrm{Na}^{+}, \mathrm{K}^{+}, \mathrm{Ca}^{2+}, \square=\right.$ vacancy), the $\mathrm{Y}$-site $\left(\mathrm{Fe}^{2+}, \mathrm{Mg}^{2+}, \mathrm{Al}^{3+}, \mathrm{Li}^{+}\right)$, and the $\mathrm{W}$-site $\left(\mathrm{OH}^{-}, \mathrm{O}^{2-}, \mathrm{F}^{-}, \mathrm{Cl}^{-}\right)$(van Hinsberg et al. 2011; Henry and Dutrow 2018), while the Z-, T-, and V-sites are usually fully occupied by $\mathrm{Al}, \mathrm{Si}$, and $(\mathrm{O}, \mathrm{OH})$, respectively.

Tourmalines in the Dachang ore district show a wide range of major element concentrations, in particular for Fe (0.20 2.41 apfu), Mg (0.00 2.87 apfu), Ca (0.00 0.64 apfu), Na (0.23 0.98 apfu), and $\mathrm{Al}$ (5.50 6.87 apfu). The minor components of $\mathrm{Mn}$ and $\mathrm{Ti}$ range from 0.00 to approximately 0.04 and 0.00 to approximately 0.07 apfu, respectively. $\mathrm{F}$ contents are variable (0.01 0.65 apfu) and Cl contents are negligible.

However, each group of tourmaline has relatively small variation ranges. Based on the $\mathrm{X}$ - and Y-site proportions, almost all Tur-M and Tur-L belong to the alkali group (Fig. 9). They have low $\mathrm{Mg} /(\mathrm{Mg}+\mathrm{Fe})$ ratios (mostly $<0.5)$, low X-site vacancy $(<0.5$ apfu), and high $\mathrm{Na} /(\mathrm{Na}+\mathrm{Ca})$ ratios (>0.85), and most plot in the schorl field (Fig. 10a-b). Most of the Tur-C belong to the alkali group, and a few belong to the X-site vacant group and the calcic group (Fig. 9). These tourmalines are Mg-rich with high $\mathrm{Mg} /(\mathrm{Mg}+\mathrm{Fe})$ ratios (>0.7) and have variable $\mathrm{Na} /(\mathrm{Na}+\mathrm{Ca})$ ratios $(0.26 \sim 0.96)$ and plot in the dravite field, overlapping slightly with the uvite and Mg-foitite field (Fig. 10a-b).

In the Al-Fe-Mg and Ca-Fe-Mg ternary diagrams of Henry and Guidotti (1985), all TurM plot in Field 2, representing tourmalines from Li-poor granitoids and associated pegmatites and aplites (Fig. 11a-b). Most of Tur-L also plot in Field 2, and a few plot in Field 3, representing tourmalines from $\mathrm{Fe}^{3+}$-rich quartz-tourmaline rocks (or hydrothermally altered granites). However, all Tur-C plot across the boundaries of Fields 4, 5, and 7 in the Al-Fe-Mg diagram (Fig. 11a) and across Fields 9, 10, and 11 in the Ca-Fe-Mg diagram (Fig. 11b). These 
fields correspond to tourmalines from largely metasedimentary terrains, with varying degrees of Al saturation (Fig. 11a) and Ca concentrations (Fig. 11b).

The large range in $\mathrm{Fe} /(\mathrm{Fe}+\mathrm{Mg})$ ratios reflects the exchange vector FeMg-1 (Fig. 12a). Given the low contents of $\mathrm{Mn}$ and $\mathrm{Li}$, values of $(\mathrm{Fe}+\mathrm{Mg})_{\text {total }}<3$ apfu for most of the tourmaline samples indicate the presence of $\mathrm{Al}$ in the $\mathrm{Y}$-site (up to $0.79 \mathrm{apfu}$ ). $\mathrm{Al}^{3+}$ is able to substitute for $\mathrm{Fe}^{2+}, \mathrm{Mg}^{2+}$, and $\mathrm{Mn}^{2+}$ at the $\mathrm{Y}$-site, with a vacant $\mathrm{X}$-site maintaining charge balance. As shown in the total Al- vs. X-site vacancy plot (Fig. 12b), this substitution is related to the vector (Ca, $\mathrm{Mg})(\square, \mathrm{Al})_{-1}$ or $(\mathrm{Na}, \mathrm{Mg})(\square, \mathrm{Al})_{-1}$. This observation is consistent with most Tur-C plotting in Field 4 of Fig. 11a, which corresponds to Al-rich metasediments.

\section{Trace element variations}

The concentrations of $>40$ trace elements in tourmaline from the Dachang ore district have been measured. The median concentrations for most trace elements range from 0.1 to $10 \mathrm{ppm}$. Higher concentrations (up to several tens to thousands of ppm) were observed for $\mathrm{Li}, \mathrm{Be}$, Sc, V, Cr, Zn, Ga, Sr, and Sn. Nb, Ta, Co, Ni, Ge, Pb, and light rare earth elements (LREE) have median concentrations of several to tens of ppm,whereas heavy REE, Rb, Y, Zr,Mo, Cd, Cs, $\mathrm{Ba}, \mathrm{Hf}, \mathrm{W}$, Th, and $\mathrm{U}$ have median concentrations of $<1 \mathrm{ppm}$.

The Tur-M has a broader range of and a higher median Li concentration (250 ppm) than the Tur-L (120 ppm) and Tur-C (33 ppm) (Fig. 13). Zn concentrations show a similar variation trend to Li (410 ppm for Tur-M, 200 ppm for Tur-L, and 170 ppm for Tur-C). The Tur-L has the highest median concentrations of Be (280 ppm), Ge (9.3 ppm), and Sn (630 ppm). Comparably, Tur-L1 show higher concentrations of Be, Sc, and Sn than Tur-L2. The Tur-C has the highest median concentrations of V (1800 ppm), Cr (180 ppm), Sc (110 ppm), and Sr (390 ppm) (Fig. 13). The Tur-C1 has higher concentrations of Li, Be, Sc, Ga, and Sr and lower concentrations of $\mathrm{V}$ and $\mathrm{Cr}$ than Tur-C2. 
The Tur-M has very low REE concentrations (Fig. 14) compared to Tur-L. In chondritenormalized patterns, most samples show a depletion of middle REE with slightly positive Eu anomalies (Fig. 14). The positive Eu anomalies are due to the preferential incorporation of $\mathrm{Eu}^{2+}$ in tourmaline (van Hinsberg, 2011). The Tur-C has lower LREE concentrations than Tur-L, but show HREE enrichments and more positive Eu anomalies (Fig. 14). More positive Eu anomalies for Tur-C might be caused by dissolution of feldspars in the strata during fluid-rock interactions.

\section{Boron isotopic compositions}

The boron isotopic compositions obtained by LA-MC-ICPMS are given in ESM Table S2. Disseminated tourmaline in the Longxianggai granite has $\delta^{11} \mathrm{~B}$ values of -15.1 to $-11.2 \%$ with an average of $-13.6 \%$ o $\pm 2.0 \%$ o $(n=20,2 \sigma)$ (Fig. 15). Tourmaline from the pegmatite has slightly lower values of -16.5 to $-12.1 \%$ with an average of $-14.8 \%$ o $\pm 1.9 \%$ o $(n=45,2 \sigma)$. Tourmaline from the quartz-tourmaline veins in the Longxinggai granite has relatively homogeneous $\delta^{11} \mathrm{~B}$ values of -15.7 to $-14.0 \%$. Tourmaline from the skarn and orebody in the Lamo deposit has $\delta^{11} \mathrm{~B}$ values of -16.4 to $-14.1 \%$. Tourmaline from one sample (T-42a) of the stratiform ore in the Changpo-Tongkeng deposit has similar $\delta 11 \mathrm{~B}$ range $(-15.7$ to $-14.9 \%$ ) to the Lamo deposit, whereas tourmaline from sample T-55 of vein-type ore in the ChangpoTongkeng deposit has lower $\delta^{11} \mathrm{~B}$ values $(-18.6$ to $-16.4 \%)$.

\section{Discussion}

Formation of tourmaline in the magmatic rocks

Before attempting to interpret the geochemical and isotopic data, it is essential to place the tourmaline occurrences in a geological context. Tourmaline is often present in boron-rich granites and related hydrothermal Sn-Wmineralized systems, such as the Cornubian Batholith (Duchoslav et al. 2017), the Heemskirk and Pieman Heads granites (Hong et al. 2017), the 
Panasqueira deposit (Codeço et al. 2017), and the Puy-les- Vignes deposit (Harlaux et al. 2019). Tourmaline in the Longxianggai granite is disseminated throughout the granite, where it coexists with quartz and plagioclase. This type of tourmaline is khaki in color, has no finescale zonation, has high $\mathrm{Fe} /(\mathrm{Fe}+\mathrm{Mg})$ ratios, and belongs to the schorl series. It also has high $\mathrm{Al}$ contents in the $\mathrm{Y}$-site $\left(\mathrm{Al}^{\mathrm{Y}}=0.23 \sim 0.64 \mathrm{apfu}\right)$. It has high concentrations of $\mathrm{Li}$ (average $200 \mathrm{ppm}$ ) and $\mathrm{Zn}$ (average $350 \mathrm{ppm}$ ). Tourmaline from the pegmatite veins in the granite has similar geochemical characteristics, consistent with a magmatic origin (London et al. 1996). Harlaux et al. (2019) proposed the use of Li/Sr ratios to discriminate magmatic and hydrothermal tourmaline. The Tur-M1 and Tur-M2 have high Nb+Ta contents (average 8.2 ppm and 17 ppm, respectively) and Li/Sr ratios (average 38 and 25, respectively) (Fig. 16a-b). Thus, the Tur-M1 and the Tur-M2 are suggested to be of primary magmatic origin.

Leucocratic peraluminous magmas that are saturated with respect to tourmaline may contain several wt. \% $\mathrm{B}_{2} \mathrm{O}_{3}$ in the bulk melt (Dingwell et al. 1996). At these concentration levels, boron serves as a flux for granitic melts, enabling them to remain liquid to lower temperatures and allowing a greater degree of crystallization fractionation (Dingwell et al. 1996). The Tur-M2 has similar Fe/(Fe+Mg) and $\mathrm{Na} /(\mathrm{Na}+\mathrm{Ca})$ ratios as Tur-M1, but show higher Li (average 350 ppm), Sc (average 27 ppm), and Ga (average 220 ppm) concentrations (Fig. 13). These elements are incompatible in most rock-forming minerals and thus generally enriched in residual melts. Crystal fractionation also tends to concentrate $\mathrm{Sn}$ in the residual melts and post-magmatic fluids. The Tur-M1 and Tur-M2 have higher Sn concentrations (average $100 \mathrm{ppm}$ and $81 \mathrm{ppm}$, respectively) than the Longxianggai granite (whole-rock Sn contents of 24 39 ppm). Indeed, many tin granites are boron-rich and contain magmatic tourmaline (Duchoslav et al. 2017; Hong et al. 2017; Zhao et al. 2019). Hong et al. (2017) suggested several geochemical indices within tourmaline (e.g., Zn/Nb, Co/Nb, Sr/Ta, Co/La) that may be used to distinguish Sn-mineralized granites from barren granites in Tasmania. 
Trace element characteristics of the Tur-M1 and Tur-M2 are similar to the magmatic tourmalines in the Sn-mineralized granites (Fig. 16c-d).

In the late magmatic-hydrothermal transition stage of granite fractional crystallization, tourmaline often occurs as tourmaline-quartz nodules or tourmaline-quartz veins in the granitic body (Trumbull et al. 2008; Hong et al. 2017; Zhao et al. 2019). The Tur-M3 from the quartztourmaline veins in the Longxianggai granite show similar $\mathrm{Fe} /(\mathrm{Fe}+\mathrm{Mg})$ ratios as the magmatic Tur-M1 (Fig. 10a). Contents of most trace elements (Li, Zn, V, Cr, Ga, Ge) in Tur-M3 are identical to those of Tur-M1 (Fig. 12). In REE patterns, Tur-M3 show positive Eu anomalies (Fig. 14), which could be caused by the dissolution of magmatic feldspars by the hydrothermal fluids (Fig. 6b). Tourmaline from the quartz-tourmaline veins may have precipitated from late magmatic-hydrothermal fluids exsolved from the Longxianggai granite.

The Tur-M1 has $\delta^{11} \mathrm{~B}$ values of -15.1 to $-11.2 \%$ with an average of $-13.6 \%{ }_{0} \pm 2.0 \%$ o $(n=20,2 \sigma)$. The melt-tourmaline fractionation of $B$ isotopes has not been determined experimentally, but likely depends on the temperature and the proportion of trigonal to tetrahedral coordination sits of boron in the melt and the tourmaline. Comparison between experimental studies of melt-fluid and fluid-tourmaline boron isotope fractionation (Hervig et al. 2002; Meyer et al. 2008; Maner IV and London 2018) suggests that the melt-tourmaline fractionation is small at magmatic temperatures of $700-800^{\circ} \mathrm{C}$, with tourmaline being 1.0 to 2.0\%o heavier than the $\delta^{11} \mathrm{~B}$ of the melt (Siegel et al. 2016). The highest $\delta^{11} \mathrm{~B}$ value measured in magmatic Tur-M1 is $-11.2 \%$, which suggests that the primary magma had a $\delta 11 \mathrm{~B}$ value of approximately -13 to $-12 \%$. This value lies well within the wide range of $\delta^{11} \mathrm{~B}$ values observed globally in S-type granites $(-10.7 \pm 3.8 \%, \mathrm{n}=179)$ (Trumbull and Slack 2018). Rayleigh fractionation will result in progressive depletion of ${ }^{11} \mathrm{~B}$ in the residual melt because the crystallized tourmaline has higher $\delta^{11} \mathrm{~B}$ values than the melt (Siegel et al. 2016; Zhao et al. 2019). The later pegmatitic Tur-M2 show lower $\delta^{11} \mathrm{~B}$ values of -16.5 to $-12.1 \%$. The $\delta^{11} \mathrm{~B}$ 
value of the parent melt may have evolved to $-19.0 \%$, given the lowest value of Tur-M2, $-16.5 \%$, and a larger melt-tourmaline fractionation factor of $-2.5 \%$ at a lower temperature of 550 to $650^{\circ} \mathrm{C}$. Alternatively, the lower $\delta^{11} \mathrm{~B}$ values in Tur-M2 may reflect exsolution and loss of ${ }^{11} \mathrm{~B}$-enriched aqueous phase, as observed in the late magmatic-hydrothermal transition stage in pegmatite systems elsewhere (Siegel et al. 2016).

The Tur-M3 precipitated from hydrothermal fluids that likely exsolved from the cooling granite. Two experimental studies and one theoretical calculation of B-isotope fractionation between tourmaline and aqueous fluid show enrichment of ${ }^{11} \mathrm{~B}$ in the fluid phase under all conditions (Palmer et al. 1992;Meyer et al. 2008; Li et al. 2020). The equilibriumfluid-tourmaline fractionation factor at $500^{\circ} \mathrm{C}$ is $+1.8 \%$ based on the fractionation of Meyer et al. (2008). The Tur-M3 from the quartz-tourmaline veins has homogeneous $\delta^{11} \mathrm{~B}$ values with an average value of $-14.7 \%$, suggesting that they precipitated from a fluid with a $\delta^{11} \mathrm{~B}$ value of $-12.9 \%$. The boron isotopic fractionation between granitic melt and aqueous fluids has been calculated to be approximately $-5 \%$ at $500^{\circ} \mathrm{C}$ (Kaliwoda et al. 2011; Trumbull et al. 2013) and suggests that the aqueous fluid exsolved from a granite melt with a $\delta^{11} \mathrm{~B}$ value of approximately $-18 \%$; which is close to the value of $-19 \%$ calculated from the Tur-M2 boron isotopic composition.

Origin and evolution of hydrothermal fluids in Lamo

The Lamo deposit is a typical skarn deposit. Previous studies showed that the skarn formation and mineralization in the Lamo deposit can be classified into four stages (Fu et al. 1993): (1) prograde skarn stage, forming garnet, vesuvianite, wollastonite, and minor diopside; (2) retrograde skarn stage, containing epidote, amphibole, fluorite, and quartz; (3) quartzsulfide stage, forming arsenopyrite, chalcopyrite, sphalerite, pyrrhotite, quartz, and fluorite; and (4) carbonate-stibnite stage. The mineralization age is $90.0 \pm 1.1 \mathrm{Ma}$, based on the molybdenite Re- 
Os dating (Zhao et al. 2018), and is consistent with the emplacement age of the Longxianggai granite (91-97 Ma, Cai et al. 2006; Liang et al. 2011).

Within the Lamo deposit, tourmaline occurs in both the skarn and sulfide ores. The tourmalines have higher $\mathrm{Mg} /(\mathrm{Mg}+\mathrm{Fe})$ and lower $\mathrm{Na} /(\mathrm{Na}+\mathrm{Ca})$ ratios than the Tur-M3 (Fig. 10) and are similar to major element compositions found in hydrothermal tourmaline from other granite-related W-Sn mineralization systems (Fig. 16), such as the Cornwall Sn deposits of England (Duchoslav et al. 2017), the Ardlethan Sn deposit of Australia (Ren et al. 1995), the Jumbo-Pearl Lake W deposit of Canada (Clarke et al. 1989), the Kaneuchi W deposit of Japan (Shibu 1984), the Panasqueira W deposit of Portugal (Codeço et al. 2017), and the Puy-lesVignes W deposit in France (Harlaux et al. 2019). The increased Mg and Ca contents reflect interactions of the fluids with the host limestone. The Tur-L shows higher contents of Be, Sc, Ge, and Sr than Tur-M3 (Fig. 13). The Devonian limestone in the Dachang district has high Sr contents (103-391 ppm, unpublished data), which can enter the fluids through water-rock interactions. High Sn contents (average 630 ppm) in Tur-L reflect that the hydrothermal fluids were highly Sn-enriched. However, the ores at the Lamo deposit have low Sn grade $(<0.1 \%)$, indicating that cassiterite did not precipitate in large quantities from hydrothermal fluids during the skarn mineralization stage. Most of Sn was retained in the fluids and transferred to distal strata.

The Tur-L has $\delta^{11} \mathrm{~B}$ values of -15.9 to $-14.6 \%$ for the skarn and -16.4 to $-14.1 \%$ for the sulfide ores. Microthermometry of fluid inclusions indicates that the temperatures of hydrothermal fluids during the skarn and the quartz-sulfide stages at the Lamo deposit were in the range of $350-500^{\circ} \mathrm{C}$ and $250-340^{\circ} \mathrm{C}$, respectively (Fu et al. 1993). The entrapment pressures are low (<700 bars); thus, a pressure correction need not be made (Fu et al. 1993). The equilibrium fluid-tourmaline fractionation at $400^{\circ} \mathrm{C}$ and $300^{\circ} \mathrm{C}$ are $+2.7 \%$ and $+3.8 \%$, respectively (Meyer et al. 2008). This implies that the $\delta^{11} \mathrm{~B}$ values of the hydrothermal fluids 
were -13.2 to $-11.9 \%$ for the skarn stage and -12.6 to $-10.3 \%$ o for the quartz-sulfide stage. These values are similar as those calculated for the hydrothermal fluids that precipitated TurM3 and are consistent with the hypothesis that the Lamo fluids were evolved magmatichydrothermal fluids exsolved from the Longxianggai granite.

\section{Origin and evolution of hydrothermal fluids in Changpo-Tongkeng}

The Tur-C from the stratiform and vein ores in the Changpo-Tongkeng deposit shows distinct chemical compositions from those of the Lamo deposit in that they have high- $\mathrm{Mg} /(\mathrm{Mg}+\mathrm{Fe})$ and low $\mathrm{Na} /(\mathrm{Na}+\mathrm{Ca}$ ) ratios (Fig. 10). The formation of Mg-rich tourmaline in submarinehydrothermal systems is well documented (Plimer and Lees 1988; Slack and Coad 1989; Slack 1996; Jiang et al. 1998). Thus, the Mg-rich tourmaline in the Changpo-Tongkeng deposit could be taken to suggest they formed in a similar setting (Jiang et al. 1999). However, Mg-rich tourmaline is not restricted to stratabound massive sulfide deposits. For example, the Rum Jungle uranium deposit of Australia (Bone 1988), the Hindu Kush tungsten deposit of Pakistan (Leake et al. 1989), the Golden Dyke dome Au deposit of Australia (Plimer 1986), the Austroalpine W deposit of Austria (Raith 1988), and the Store Malene W deposit of Greenland (Appel and Garde 1987) are all stratabound deposits that contain Mg-rich tourmaline (Fig. 17). In these cases, the Mg-rich tourmaline may arise from the following: (1) formation from Mg-rich fluids of either evolved seawater or evaporitic origin (Plimer 1987, 1994; Mercadier et al. 2012; Adlakha et al. 2017), (2) formation by metamorphism-induced sulfide-silicate reactions (Ito and Plimer 1987), and/ or (3) formation by replacement of Mg-rich clastic sediments at low water/rock conditions.

The boron isotope data from tourmaline at the Changpo- Tongkeng deposit provide some constraints on these potential mechanisms. The Tur-C samples have low $\delta^{11} \mathrm{~B}$ values of -18.6 to $-14.9 \%$ (Fig. 15). The temperatures of the hydrothermal fluids responsible for the mineralization at Changpo-Tongkeng were likely $200-400^{\circ} \mathrm{C}$ by micro-thermometry of fluid 
inclusions (Fu et al. 1993). Given that the equilibrium fluid-tourmaline fractionations at $200^{\circ} \mathrm{C}$ and $400^{\circ} \mathrm{C}$ are +5.3 and $+2.7 \%$, respectively (Meyer et al. 2008), this suggests that the hydrothermal fluids had $\delta^{11} \mathrm{~B}$ values in the range of -14.9 to $-9.6 \%$. The Tur- $\mathrm{C} \delta^{11} \mathrm{~B}$ values are lower than those observed in most other tourmalines from stratiform sulfide deposits in metasedimentary and metavolcanic terrains elsewhere (typically -10 to $-2 \%$ ) (Palmer and Slack 1989; Palmer 1991). Fluids originating from marine brines generally show positive $\delta^{11} \mathrm{~B}$ values (>+20\%o, Mercadier et al. 2012; Adlakha et al. 2017). The only exception is tourmaline from the Broken Hill deposit, Australia, where $\delta^{11} \mathrm{~B}$ values as low as $-23 \%$ are recorded (Slack et al. 1989, 1993). For Broken Hill, however, there is evidence that the tourmaline $\delta^{11} \mathrm{~B}$ compositions reflect derivation from non-marine evaporates and the effects of granulite-facies metamorphism, neither of which are appropriate to the Dachang area. The $\delta^{11} \mathrm{~B}$ values of hydrothermal fluids for the Changpo-Tongkeng deposit (-14.9 to -9.6\%) are identical to those of fluids exsolved from the Longxianggai granite. Thus, we suggested that the tin-rich hydrothermal fluids were of magmatic-hydrothermal origin and are related to the Longxianggai granite.

However, in contrast to magmatic-hydrothermal Tur-M3, the Tur-C is extremely Mgrich and has higher Sc, V, and Cr contents (Fig. 13), suggesting that the fluids might have experienced reactions with volcanic rocks (Fig. 16a-b). Pan et al. (1993) reported the presence of stratabound anorthites in the Devonian strata in theDachang district. Liu et al. (2012) found intermediate and mafic volcanic rocks (basalt and andesite) intercalated in the Middle-Upper Devonian strata. Higher Sr contents and more positive Eu anomalies in the Tur-C also suggest more intensive interactions between fluids and these plagioclase-rich rocks. In the case of the Changpo-Tongkeng deposit, there is direct evidence of a nearby magmatic source of boron and the calculated $\delta^{11} \mathrm{~B}$ values of the fluids precipitating tourmaline fall within the range of fluids that are known to have formed the magmatic Tur-M. Thus, we suggest that the Mg-rich Tur-C 
was formed from hydrothermal fluids exsolved from the granite and interacting with preexisting volcanic rocks in the Devonian strata.

\section{Conclusions}

1. Tourmaline is abundant in the Dachang Sn-polymetallic ore district, with three main occurrences: in the Longxianggai granite and pegmatite veins, in the skarn and sulfide ores in the Lamo Zn-Cu deposit, and in the stratiform and vein-type ores in the Changpo-Tongkeng Sn-Pb-Zn deposit.

2. Tourmalines disseminated in the Longxianggai granite and pegmatite veins are Fe-rich schorls. They have high contents of Li, Zn, and Ga and likely have a magmatic origin. The $\delta^{11} \mathrm{~B}$ value of primary granite magma is estimated to be about $-13 \%$. Tourmaline from the quartz-tourmaline veins in the Longxianggai granite has similar chemical compositions to the magmatic tourmaline and likely formed from hydrothermal fluids exsolved from the granite melt. The $\delta^{11} \mathrm{~B}$ value of these fluids is calculated to be about $-13 \%$.

3. Tourmaline from the skarn and sulfide ores in the Lamo deposits has higher $\mathrm{Mg} /(\mathrm{Mg}+\mathrm{Fe})$ and lower $\mathrm{Na} /(\mathrm{Na}+\mathrm{Ca})$ ratios than magmatic tourmaline. The hydrothermal fluids had $\delta^{11} \mathrm{~B}$ values of -13 to $-10 \%$, suggesting that they were also formed from magmatic-hydrothermal fluids.

4. Tourmalines from the stratiform and vein ores in the Changpo-Tongkeng deposit show distinct Mg-rich, dravite compositions. They also have high concentrations of V, Sc, Cr, and Sr. The hydrothermal fluids had $\delta^{11} \mathrm{~B}$ values in the range of -15 to $-10 \%$, consistent with a magmatic-hydrothermal origin. The origin of these tourmalines may therefore reflect fluid/rock interaction of granite-derived magmatic-hydrothermal fluids with the Devonian strata. 
Acknowledgements This study is financially supported by the National Key R \& D Plan projects (No. 2017YFC061404 and No. 2016YFC0600205), the National Natural Science Foundation of China projects (No. 41673043, No. 91755208), and the special fund from the State Key Laboratory of Geological Processes and Mineral Resources (No. MSFGPMR03-2). The authors are very grateful to Editor-in-Chief Prof. Georges Beaudoin and Associate Editor Prof. Robert Linnen for the editorial handling and constructive comments of this paper. Dr. Matthieu Harlaux, Dr. Rongqing Zhang, and an anonymous reviewer are thanked for their constructive reviews, which improved this paper significantly.

\section{References}

Adlakha EE, Hattori K, Davis WJ, Boucher B (2017) Characterizing fluids associated with the McArthur River U deposit, Canada, based on tourmaline trace element and stable (B, H) isotope compositions. Chem Geol 466:417-435

Albert C, Lana C, Gerdes A, Schannor M, Narduzzi F, Queiroga G (2018) Archean magmatichydrothermal fluid evolution in the Quadrilátero Ferrífero (SE Brazil) documented by B isotopes (LA MC-ICPMS) in tourmaline. Chem Geol 481:95-109

Bone Y (1988) The geological setting of tourmalinite at Rum Jungle, N.T., Australia-Genetic and economic implications. Mineral Deposit 23:34-41

Boynton WL (1984) Geochemistry of the rare earth elements: meteorite studies. In: Henderson P (ed) Rare earth element geochemistry. Elsevier, Amsterdam, pp 63-114

Cai MH, He LQ, Liu GQ, Wu DC, Huang HM (2006) SHRIMP zircon U-Pb dating of the intrusive rocks in the Dachang tin-polymetallic ore field, Guangxi and their geological significance. Geol Rev 52: 409-414 (in Chinese with English abstract) 
Cai MH, Mao JW, Liang T, Pirajno F, Huang HL (2007) The origin of the Tongkeng-Changpo tin deposit, Dachang metal district, Guangxi, China: clues from fluid inclusions and He isotope systematics. Mineral Deposit 24:613-626

Chen YC, Huang MZ, Xu J, Hu YZ, Tang SH, Li YQ, Meng LK (1993) Tin deposits of Dachang. Geological Publishing House, Beijing, pp 1-361 (in Chinese with English abstract)

Clarke DB, Reardon NC, Chatterjee AK, Gregorie DC (1989) Tourmaline composition as a guide to mineral exploration: a reconnaissance study from Nova Scotia using discriminant function analysis. Econ Geol 84:1921-1935

Codeço MS, Weis P, Trumbull RB, Pinto F, Lecumberri-Sanchez P, Wilke FDH (2017) Chemical and boron isotopic composition of hydrothermal tourmaline from the Panasqueira W-Sn-Cu deposit, Portugal. Chem Geol 468:1-16

Dingwell DB, Pichavant M, Holtz F (1996) Experimental studies of boron in granitic melts. In: Grew ES, Anovitz LM (eds) Boron: Mineralogy, petrology and geochemistry, Rev Mineral, vol 33, pp 331-386

Duchoslav M, Marks MAW, Drost K, McCammon C, Marschall HR, Wenzel T,Markl G (2017) Changes in tourmaline composition during magmatic and hydrothermal processes leading to tin-ore deposition: the Cornubian Batholith, SW England. Ore Geol Rev 83: 215234

Dyar MD, Wiedenbeck M, Robertson D, Cross LR, Delaney JS, Ferguson K, Francis CA, Grew ES, Guidotti CV, Hervig RL, Hughes JM, Husler J, Leeman W, McGuire AV, Rhede D, Rothe H, Paul RL, Richards I, Yates M (2001) Reference materials for the microanalysis of light elements. Geostand Newsletter 25:441-463 
Fan DL, Zhang T, Ye J, Pašava J, Kribek B, Dobes P, Varrin I, Zak K (2004) Geochemistry and origin of tin-polymetallic sulfide deposits hosted by the Devonian black shale series near Dachang, Guangxi, China. Ore Geol Rev 24:103-120

Fu M, Changkakoti A, Krouse HR, Gray J, Kwak TAP (1991) An oxygen, hydrogen, sulfur, and carbon isotope study of carbonate replacement (skarn) tin deposits of the Dachang tin field, China. Econ Geol 86:1683-1703

Fu M, Kwak TAP, Mernagh TP (1993) Fluid inclusion studies of zoning in the Dachang tinpolymetallic ore field, People’s Republic of China. Econ Geol 88:283-300

Guo J, Zhang RQ, SunWD, LingMX, Hu YB,Wu K, LuoM, Zhang LC (2018) Genesis of tindominant polymetallic deposits in the Dachang district, South China: Insights from cassiterite U-Pb ages and trace element compositions. Ore Geol Rev 95:863-879

Han F, Zhao RS, Shen JZ, Hutchinson RW, Jiang SY, Chen HD (1997) Geology and origin of ores in the Dachang tin-polymetallic ore field. Geological Publishing House, Beijing, pp 1213 (in Chinese with English abstract)

Harlaux M, Mercadier J, Marignac C, Villeneuve J, Mouthier B, Cuney M (2019) Origin of the atypical Puy-les-Vignes W breccia pipe (Massif Central, France) constrained by trace element and boron isotopic composition of tourmaline. Ore Geol Rev 114:103132

Harlaux M, Kouzmanov K, Gialli S, Laurent O, Rielli A, Dini A, Chauvet A, Menzies A, Kalinaj M, Fontboté L (2020) Tourmaline as a tracer of late-magmatic to hydrothermal fluid evolution: the world-class San Rafael tin (-copper) deposit. Peru. Economic Geology 115: 1665-1697. https://doi.org/10.5382/econgeo.4762

Heinrich CA (1990) The chemistry of hydrothermal tin(-tungsten) ore deposits. Econ Geol 85:457-481

Hennigh Q, Hutchinson RW (1999) Cassiterite at Kidd Creek: an example of volcanogenic massive sulfide-hosted tin mineralization. Econ Geol Monograph 10:431-440 
Henry DJ, Dutrow BL (2018) Tourmaline studies through time: contributions to scientific advancements. J Geosci 63:77-98

Henry DJ, Guidotti CV (1985) Tourmaline as a petrogenetic indicator mineral: an example from the staurolite-grade metapelites of NW Maine. Am Mineral 70:1-15

Henry DJ, NováK M, Hawthorne FC, Ertl A, Dutrow BL, Uher P, Pezzotta F (2011) Nomenclature of the tourmaline-supergroup minerals. Am Mineral 96:895-913

Hervig RL, Moore GM, Williams LB, Peacock SM, Holloway JR, Roggensack K (2002) Isotopic and elemental partitioning of boron between hydrous fluid and silicate melt. Am Mineral 87:769-774

Hong W, Cooke DR, Zhang L, Fox N, Thompson J (2017) Tourmalinerich features in the Heemskirk and Pieman Heads granites from western Tasmania, Australia: characteristics, origins and implications for tin mineralization. Am Mineral 102:876-899

Ito T, Plimer IR (1987) The significance of tourmaline in the stratiform Dome Rock deposit, Australia. Mining Geol 37:403-418

Jiang SY (2001) Boron isotope geochemistry of hydrothermal ore deposits in China: a preliminary study. Physic Chem Earth (A) 26: 851-858

Jiang SY, PalmerMR, Slack JF, Shaw DR (1998) Paragenesis and chemistry of multistage tourmaline formation in the Sullivan Pb-Zn-Ag deposit, British Columbia. Econ Geol 93:47-67

Jiang SY, Han F, Shen JZ, Palmer MR (1999) Chemical and Rb-Sr, Sm-Nd isotopic systematics of tourmaline from the Dachang Snpolymetallic ore deposit, Guangxi Province. P. R. China. Chem Geol 157:49-67

Jiang SY, Palmer MR, Yeats CJ (2002) Chemical and boron isotopic compositions of tourmaline from the Archean Big Bell and Mount Gibson gold deposits, Murchison Province, Yilgarn Craton, Western Australia. Chem Geol 188:229-247 
Jochum KP, Willbold M, Raczek I, Stoll B, Herwig K (2005) Chemical characterization of the USGS reference glasses GSA-1G, GSC-1G, GSD-1G, GSE-1G, BCR-2G, BHVO-2G and BIR-1G using EPMA, ID-TIMS, ID-ICP-MS and LA-ICP-MS. Geostand Geoanal Res 29:285-302

Jochum KP, Weis U, Stoll B, Kuzmin D, Yang Q, Raczek I, Jacob DE, Stracke A, Birbaum K, Frick DA, Günther D, Enzweiler J (2011) Determination of reference values for NIST SRM 610-617 glasses following ISO guidelines. Geostand Geoanal Res 35:397-429

KaliwodaM, Marschall HR, MarksMAH, Ludwig T, Altherr R, Markl G (2011) Boron and boron isotope systematics in the peralkaline ilímaussaq intrusion (South Greenland) and its granitic country rocks: a record of magmatic and hydrothermal processes. Lithos 125:5164

Kalliomäki H, Wagner T, Fusswinkel T, Sakellaris G (2017) Major and trace element geochemistry of tourmalines from Archean orogenic gold deposits: proxies for the origin of gold mineralizing fluids? Ore Geol Rev 91:906-927

Lambert-Smithm JS, Rocholl A, Treloar PJ, Lawrence DM (2016) Discriminating fluid source regions in orogenic gold deposits using B-isotopes. Geochim Cosmochim Acta 194:57-76

Leake RC, Fletcher CJN, Haslam HW, Khan B (1989) Origin and tectonic setting of stratabound tungsten mineralization within the Hindu Kush of Pakistan. J Geol Society (London) 146:1003-1016

Lehmann B (1990) Metallogeny of tin. Lecture Notes in Earth Sciences 32. Springer, Berlin, $1-211$

Li XH, Li WX, Li ZX, Lo CH, Wang J, Ye MF, Yang YH (2009) Amalgamation between the Yangtze and Cathaysia Blocks in South China: constraints from SHRIMP U-Pb zircon ages, geochemistry and Nd-Hf isotopes of the Shuangxiwu volcanic rocks. Precam Res 174:117128 
Li X, Zhao KD, Jiang SY, Palmer MR (2019) In-situ U-Pb geochronology and sulfur isotopes constrain the metallogenesis of the giant Neves Corvo deposit, Iberian Pyrite Belt. Ore Geol Rev 105:223-235

Li YC, Chen HW, Wei HZ, Jiang SY, Palmer MR, van de Ven TGM, Hohl S, Lu JJ, Ma J (2020) Exploration of driving mechanisms of equilibrium boron isotope fractionation in tourmaline group minerals and fluid: a density functional theory study. Chem Geol 536: 119466

Liang T, Chen YC, Wang DH, Cai MH (2008) The geological and geochemical characteristics of Dachang tin-polymetallic deposit, Guangxi. Geological Publishing House, Beijing, pp 1235 (in Chinese with English abstract)

Liang T, Wang DH, Hou KJ, Li HQ, Huang HM, Cai MH, Wang DM (2011) LA-MC-ICPMSzirconU-Pb dating of Longxianggai pluton in Dachang of Guangxi and its geological significance. Acta Petrol Sinica 27:1624-1636 (in Chinese with English abstract)

Liu YS, Gao S, Hu ZC, Gao CG, Zong KQ,Wang DB (2010) Continental and oceanic crust recycling-induced melt-peridotite interactions in the trans-North China Orogen: $\mathrm{U}-\mathrm{Pb}$ dating, Hf isotopes and trace elements in zircons from mantle xenoliths. J Petrol 51:537571

Liu CM, Qin DX, Yan YF (2012) The discovery of the intermediate and basic volcanic rocks in the Dachang ore deposit, Guangxi, and its geological significance. Acta Petrol Mineral 31(1):73-78 (in Chinese with English abstract)

London D, Morgan GB, Wolf MB (1996) Boron in granitic rocks and their contact aureoles. In: Grew ES, Anovitz LM (eds) Boron: Mineralogy, Petrology and Geochemistry. Rev Mineral, vol 33, pp 299-330

Maner JL IV, London D (2018) Fractionation of the isotopes of boron between granitic melt and aqueous solution at $700^{\circ} \mathrm{C}$ and $800^{\circ} \mathrm{C}(200 \mathrm{MPa})$. Chem Geol 489:16-27 
Mao JW (1995) Tourmalinite from northern Guangxi, China. Mineral Deposit 30:235-245

Mao JW, Cheng YB, Guo GL, Yang ZX, Feng JR (2008) Gejiu tin polymetallic ore-field: deposit model and discussion for several points concerned. Acta Geol Sinica 82(11):14551467 (in Chinese with English abstract)

Mercadier J, Richard A, Cathelineau M (2012) Boron- and magnesium-rich marine brines at the origin of giant unconformity-related uranium deposits: ${ }^{11} \mathrm{~B}$ evidence from $\mathrm{Mg}$ tourmalines. Geology 40:231-234

Meyer C, Wunder B, Meixner A, Romer RL, HeinrichW (2008) Boron isotope fractionation between tourmaline and fluid: an experimental re-investigation. Contrib Mineral Petrol 156:259-267

Morgan GB (2016) A spreadsheet for calculating normative mole fractions of end-member species for Na-Ca-Li-Fe ${ }^{2+}-\mathrm{Mg}-\mathrm{Al}$ tourmalines from electron microprobe data. Am Mineral 101:111-119

PalmerMR (1991) Boron isotope systematics of hydrothermal fluids and tourmalines: a synthesis. Chem Geol 94:111-121

Palmer MR, Slack JF (1989) The boron isotope composition of tourmalines from massive sulfide deposits and tourmalinites. Contrib Mineral Petrol 103:434-451

Palmer MR, London D, Morgan GBVI, Babb HA (1992) Experimental determination of fractionation of ${ }^{11} \mathrm{~B} /{ }^{10} \mathrm{~B}$ between tourmaline and aqueous vapor: a temperature- and pressure-dependent isotopic system. Chem Geol 101:123-129

Pan JH, Amstutz GC, Moh C (1993) Stratabound anorthites in the Dachang Sn-polymetallic ore field, Guangxi, China. Chinese J Geochem 12:261-269

Petersen EU (1986) Tin in volcanogenic massive sulfide deposits: an example from the Geco mine, Manitouwadge district, Ontario, Canada. Econ Geol 81:323-342 
Plimer IR (1986) Tourmalinites from the Golden Dyke dome, northern Australia. Mineral Deposit 21:263-270

Plimer IR (1987) The association of tourmalinite with stratiform scheelite deposits. Mineral Deposit 22:282-291

Plimer IR (1994) Strata-bound scheelite in meta-evaporites, Broken Hill, Australia. Econ Geol 89:423-437

Plimer IR, Lees TC (1988) Tourmaline-rich rocks associated with the submarine hydrothermal Rosebery Zn-Pb-Cu-Ag-Au deposit and granites in western Tasmania, Australia. Mineral Petrol 38:81-103

Raith JG (1988) Tourmaline rocks associated with stratabound scheelite mineralization in the Austroalpine Crystalline Complex, Austria. Mineral Petrol 39:265-288

Ranta JP, Hanski E, Cook N, Lahaye Y (2017) Source of boron in the Palokas gold deposit, northern Finland: evidence from boron isotopes and major element composition of tourmaline. Mineral Deposit 52:733-746

Relvas JMRS, Tassinari CC, Munhá J, Barriga FJ (2001) Multiple sources for ore-forming fluids in the Neves Corvo VHMS deposit of the Iberian Pyrite Belt (Portugal): strontium, neodymium and lead isotope evidence. Mineral Deposit 36:416-427

Ren SK,Walshe JL, Paterson RG, Both RA, Andrew A (1995) Magmatic and hydrothermal history of the porphyry-style deposits of the Ardlethan tin field, New South Wales, Australia. Econ Geol 90: 1620-1645

Sciuba M, Beaudoin G, Makvandi S (2020) Chemical composition of tourmaline in orogenic gold deposits. Mineral Deposit doi. https://doi.org/10.1007/s00126-020-00981-x

Shibu T (1984) Chemical compositions of tourmaline in the vein-type tungsten deposits in the Kaneuchi mine, Japan. Mineral Deposit 19: 298-303 
Siegel K, Wagner T, Trumbull RB, Jonsson E, Matalin G, Wälle M, Heinrich CA (2016) Stable isotope $(\mathrm{B}, \mathrm{H}, \mathrm{O})$ and mineralchemistry constraints on the magmatic to hydrothermal evolution of the Varuträsk rare-element pegmatite (northern Sweden). Chem Geol 421:116

Slack JF (1996) Tourmaline associations with hydrothermal ore deposits. In: Grew ES, Anovitz LM (eds) Boron: Mineralogy, petrology and geochemistry, Rev Mineral, vol 33, pp 559_ 643

Slack JF, Coad PR (1989) Multiple hydrothermal and metamorphic events in the Kidd Creek volcanogenic massive sulphide deposit, Timmins, Ontario: evidence from tourmalines and chlorites. Can J Earth Sci 26:694-715

Slack JF, Trumbull RB (2011) Tourmaline as a recorder of ore-forming processes. Elements $7: 321-326$

Slack JF, Palmer MR, Stevens BPJ (1989) Non-marine evaporites in the Proterozoic Broken Hill Block, Australia: evidence from boron isotopes and implications for ore genesis. Nature 342:913-916

Slack JF, Palmer MR, Stevens BPJ, Barnes RG (1993) Origin and significance of tourmalinerich rocks in the Broken Hill District. Econ Geol 88:505-541

Su ZK, Zhao XF, Li XC, Zhou MF (2016) Using elemental and boron isotopic compositions of tourmaline to trace fluid evolutions of IOCG systems: the worldclass Dahongshan Fe-Cu deposit in SW China. Chem Geol 441:265-279

Su ZK, Zhao XF, Zeng LP, Zhao KD, Hofstra AH (2019) Tourmaline boron and strontium isotope systematics reveal magmatic fluid pulses and external fluid influx in a giant iron oxide-apatite (IOA) deposit. Geochim Cosmochim Acta 259:233-252

Tonarini S, Pennisi M, Adorni-Braccesi A, Dini A, Ferrara G, Gonfiantini R, Wiedenbeck M, Gröning M (2003) Intercomparison of boron isotope and concentration measurements. Part 
I: selection, preparation and homogeneity tests of the intercomparison materials. Geostand Geoanaly Res 27:21-39

Trumbull RB, Slack JF (2018) Boron isotopes in the continental crust: granites, pegmatites, felsic volcanic rocks, and related ore deposits. In: Marschall H, Foster G (eds) Boron isotopes: the fifth element. Springer, Switzerland, pp 249-272

Trumbull RB, Krienitz MS, Gottesmann B, Wiedenbeck M (2008) Chemical and boron-isotope variations in tourmalines from an S-type granite and its source rocks: the Erongo granite and tourmalinites in the Damara Belt, Namibia. Contrib Mineral Petrol 155:1-18

Trumbull RB, Beurlen H, Wiedenbeck M, Soares DR (2013) The diversity of B-isotope variations in tourmaline form rare-element pegmatites in the Borborema Province of Brazil. Chem Geol 352:47-62

Trumbull RB, Garda GM, Xavier RP, Cavalcanti JAD, Codeço MS (2019) Tourmaline in the Passagem de Mariana gold deposit (Brazil) revisited: major-element, trace-element and Bisotope constraints on metallogenesis. Mineral Deposit 54:395-414

van Hinsberg VJ, Henry DJ, Dutrow BL (2011) Tourmaline as a petrologic forensic mineral: a unique recorder of its geologic past. Elements 7:327-332

Zhao KD, Jiang SY (2007) Rare earth element and yttrium analyses of sulfides from the Dachang Sn-polymetallic ore field, Guangxi Province, China: implication for ore genesis. Geochem J 41:121-134

Zhao KD, Jiang SY, Xiao HQ, Ni P (2002) Origin of ore-forming fluids of the Dachang Snpolymetallic ore deposit: evidence from helium isotopes. Chinese Sci Bull 47:1041-1045

Zhao KD, Jiang SY, Ni P, Ling HF, Jiang YH (2007) Sulfur, lead and helium isotopic compositions of sulfide minerals from the Dachang Sn-polymetallic ore district in South China: implication for ore genesis. Mineral Petrol 89:251-273 
Zhao H, Su W, Xie P, Shen N, Cai J, Luo M, Li J, Bao Z (2018) Re-Os dating of molybdenite and in-situ $\mathrm{Pb}$ isotopes of sulfides from the Lamo $\mathrm{Zn}-\mathrm{Cu}$ deposit in the Dachang tinpolymetallic ore field, Guangxi, China. Acta Geochimica 37:384-394

Zhao HD, Zhao KD, Palmer MR, Jiang SY (2019) In-situ elemental and boron isotopic variations of tourmaline from the Sanfang granite, South China: insights into magmatichydrothermal evolution. Chem Geol 504:190-204 


\section{Figure Captions}

Figure 1. Geological map showing the distribution of granite and Sn-polymetallic ore districts in theYoujiang Basin, South China (modified after Guo et al. 2018)

Figure 2. Geological map showing the occurrence of the Dachang ore district in the Danchi Trough in the Youjiang Basin (modified after Han et al. 1997)

Figure 3. Geological map of the Dachang Sn-polymetallic ore district (modified after Jiang et al. 1999)

Figure 4. Generalized stratigraphic column of the Dachang Sn-polymetallic ore district (modified after Jiang et al. 1999)

Figure 5. Cross-section from the Changpo-Tongkeng deposit to the Lamo deposit (modified after Jiang et al. 1999)

Figure 6. a Representative specimen of the Longxianggai granite. b Photomicrograph of disseminated tourmaline (Tur-M1) in the Longxianggai granite. The tourmaline crystals are euhedral to subhedral and intergrown with quartz and plagioclase. c Tourmaline-bearing pegmatite vein hosted by the Longxianggai granite. $\mathbf{d}$ Photomicrograph of tourmaline crystals (Tur-M2) in the pegmatite vein. e Tourmaline-quartz vein hosted in the Longxianggai granite. f Photomicrograph of tourmaline crystals (Tur-M3) in the quartz vein. Tur tourmaline, Pl plagioclase, Qz quartz

Figure 7. a Skarn sample from the Lamo deposit. b Photomicrograph of tourmaline crystals (Tur-L1) in the skarn sample. c Sulfide ore sample from the Lamo deposit. d Photomicrograph of tourmaline crystals (Tur-L2) in the sulphide ore. e-f BSE images of tourmaline crystals (Tur-L2) in the sulphide ore samples. The tourmaline is intergrown with arsenopyrite, fluorite, and quartz and locally contains cassiterite, fluorite, and apatite. Tur tourmaline, Qz quartz, Cst cassiterite, Ap apatite, Fl fluorite, Apy arsenopyrite 
Figure 8. a Bedded ore sample from the Changpo-Tongkeng deposit. b Photomicrograph of tourmaline crystals (Tur-C1) from the bedded ores. Tourmaline occurs as euhedral columnar crystals intergrown with the sphalerite. c-d BSE images of tourmalines in the bedded ores. e Vein ore sample from the Changpo-Tongkeng deposit. f Photomicrograph of tourmaline crystals (Tur-C2) in the vein ores. Tur tourmaline, Sp sphalerite, Py pyrite

Figure 9. Classification diagram of all tourmalines from the Dachang district based on X-site occupancy (after Henry et al. 2011)

Figure 10. Classification of tourmalines from the Dachang district based on the calculated $\mathrm{Mg} /(\mathrm{Mg}+\mathrm{Fe})$ vs. $\mathrm{Na} /(\mathrm{Na}+\mathrm{Ca})$ (a) and $\mathrm{Mg} /(\mathrm{Mg}+\mathrm{Fe})$ vs. X-site vacancy (b)

Figure 11. Ternary Al-Fe-Mg and Ca-Fe-Mg diagrams showing compositional variations of tourmalines from the Dachang district. The regions define the compositions of tourmaline from different rock types, according to Henry and Guidotti (1985). 1, Li-rich granitoids and associated pegmatites and aplites; 2, Li-poor granitoids and associated pegmatites and aplites; 3, $\mathrm{Fe}^{3+}$-rich quartz-tourmaline rocks (hydrothermally altered granites); 4, metapelites and metapsammites coexisting with an Al-saturating phase; 5, metapelites and metapsammites not coexisting with an Al-saturating phase; 6, Fe3+-rich quartz-tourmaline rocks, calc silicate rocks, and metapelites; 7, low Ca metaultramafics and Cr- and V-rich metasediments; 8, metacarbonates and metapyroxenites; 9, Ca-rich metapelites, metapsammites, and calc-silicate rocks; 10, Ca-poor metapelites, metapsammites, and quartz-tourmaline rocks; 11, metacarbonates; 12, metaultramafics

Figure 12. a Plot of Mg vs. Fe. b Plot of Al vs. X-site vacancy of cation occupancies in tourmalines from the Dachang district

Figure 13. Box whisker plots showing comparisons of representative trace elements in different types of tourmaline from the Dachang district 
Figure 14. Chondrite-normalized REE patterns of tourmalines from the Dachang district. The normalization values of chondrite are from Boynton (1984)

Figure 15. Histograms of B isotopic compositions of tourmalines from the Dachang district Figure 16. a Plot of Li/Sr vs. $\mathrm{Nb}+\mathrm{Ta}$. b Plot of $\mathrm{Li} / \mathrm{Sr}$ vs. $\mathrm{Cr}+\mathrm{V}$. c Plot of $\mathrm{Sn}$ vs. Zn/Nb. d Plot of Sn vs. Co/Nb. Chemical fields of I-III came from Harlaux et al. (2019), and chemical fields of IV-V came from Hong et al. (2017)

Figure 17. Comparisons in Al-Fe- Mg diagram of tourmalines from the representative graniterelated W-Sn deposits and exclusively stratabound massive sulphide deposits 
Figure 1.

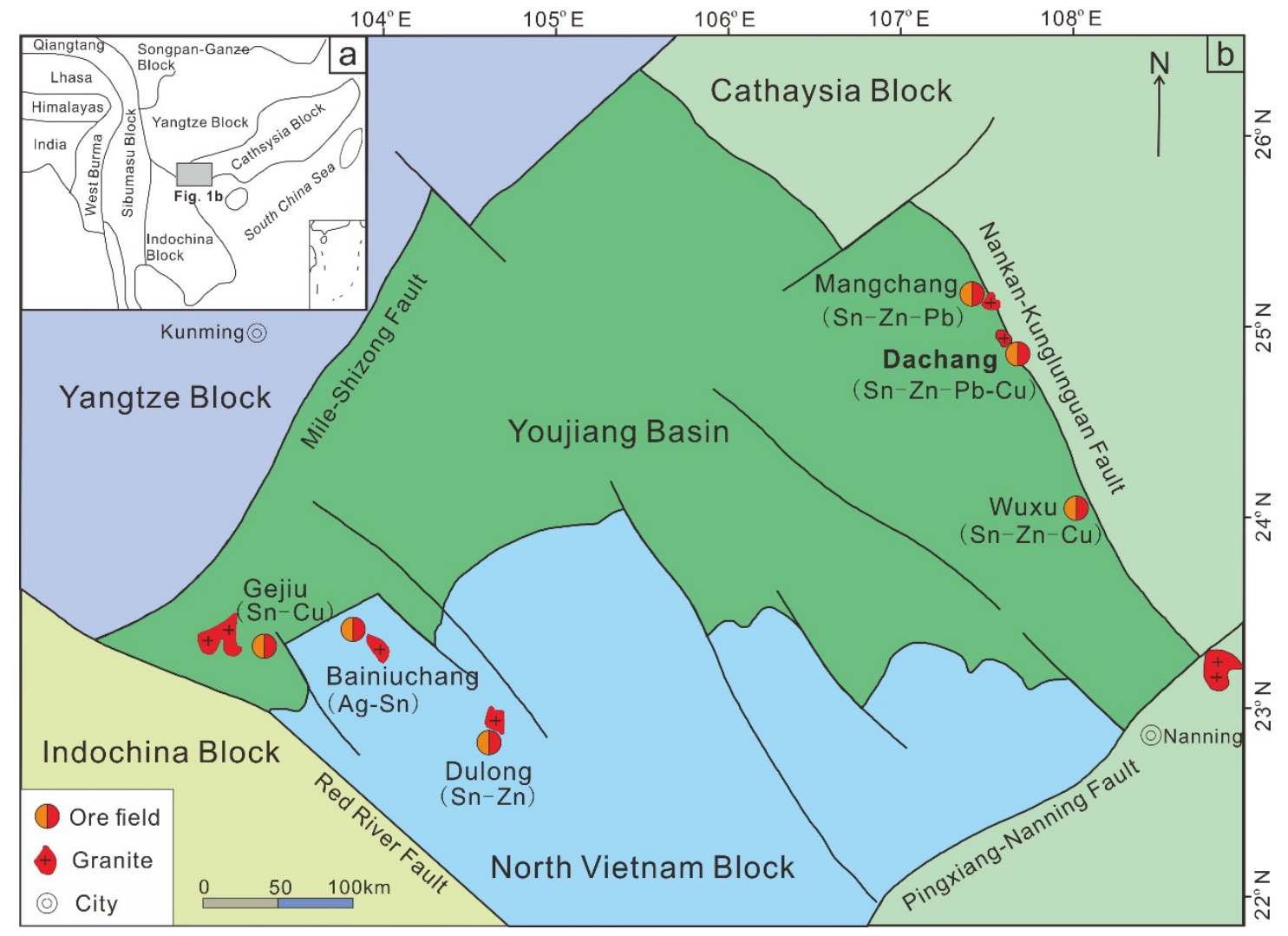


Figure 2.

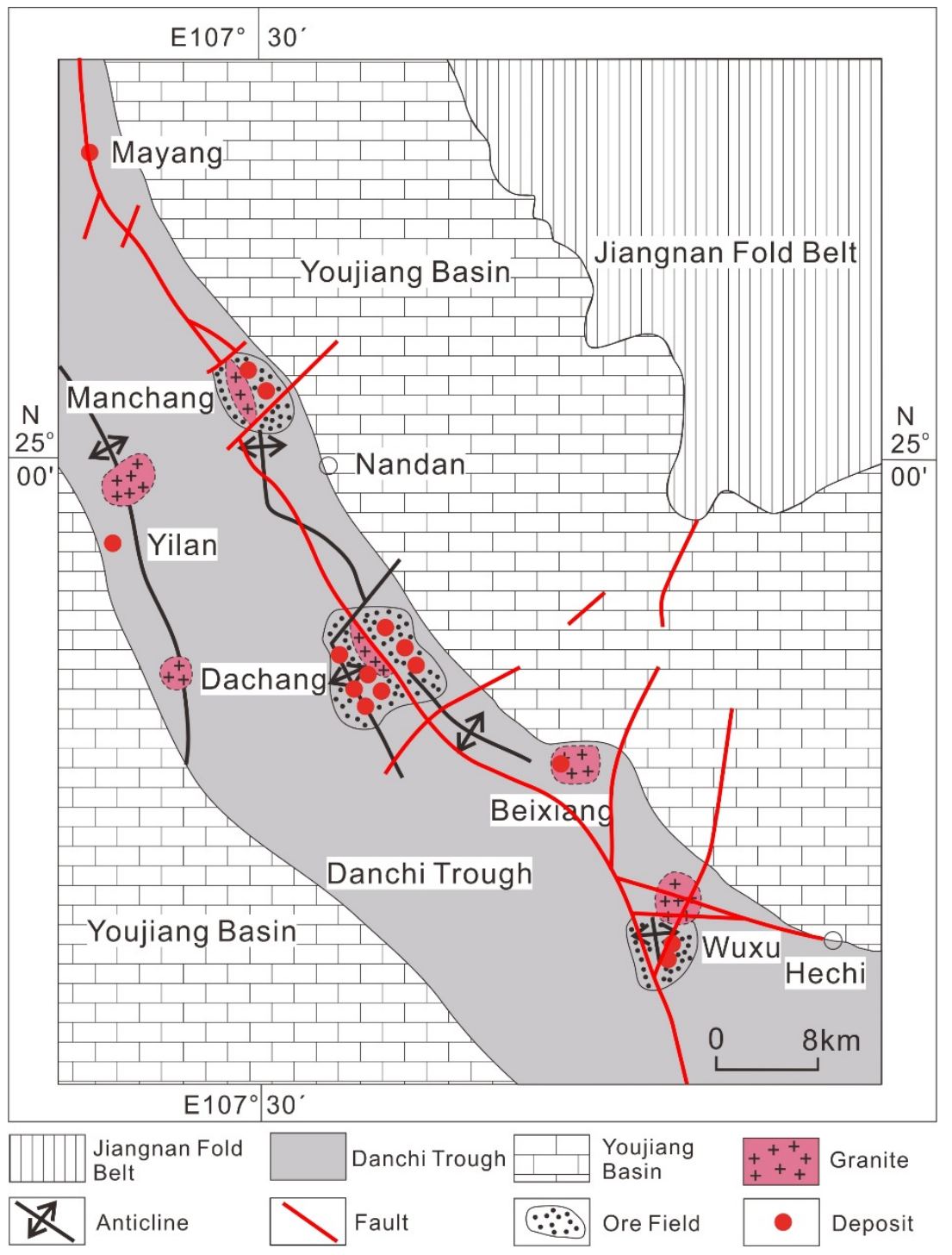


Figure 3.

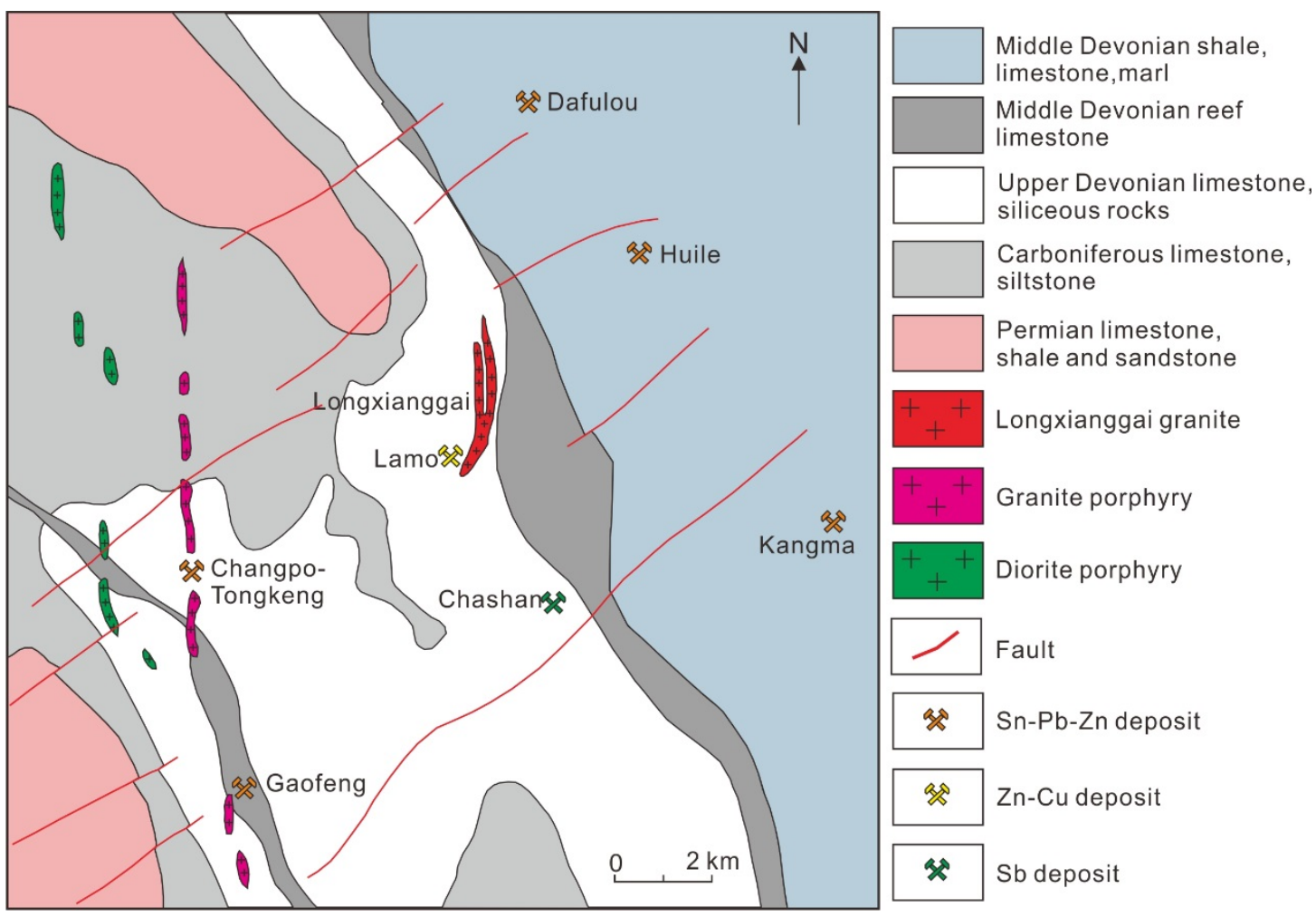


Figure 4.

\begin{tabular}{|c|l|l|}
\hline & Orebody & \multicolumn{1}{|c|}{ Lithology } \\
\hline & Notratigraphy & Non to dark-gray limestone with small \\
lenticules and black chert, 70 110m thick
\end{tabular}


Figure 5.
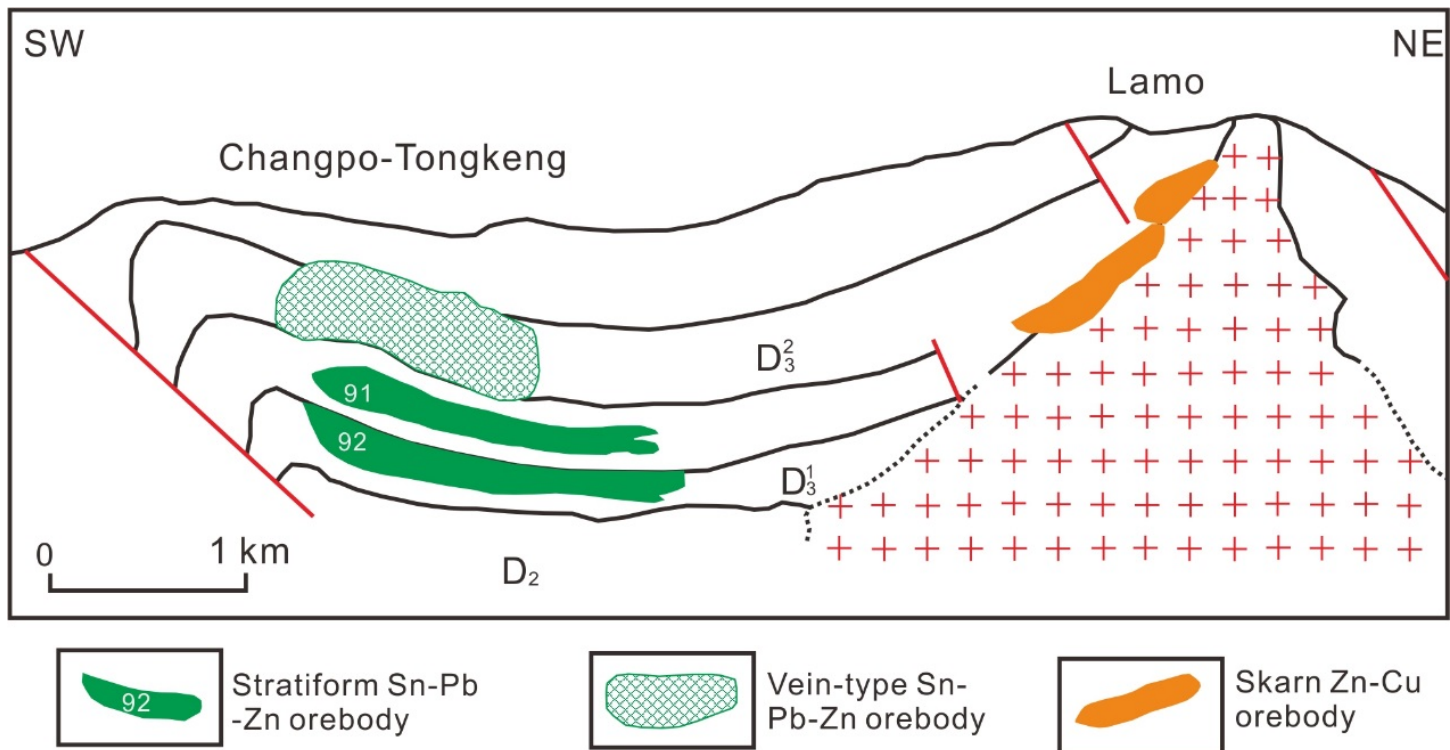

Skarn Zn-Cu

Zn orebody

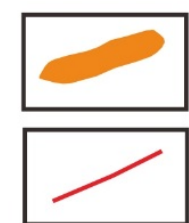

orebody

++ Granite

(Longxianggai)

$\mathrm{D}_{2}$

Devonian Strata

Fault 
Figure 6.
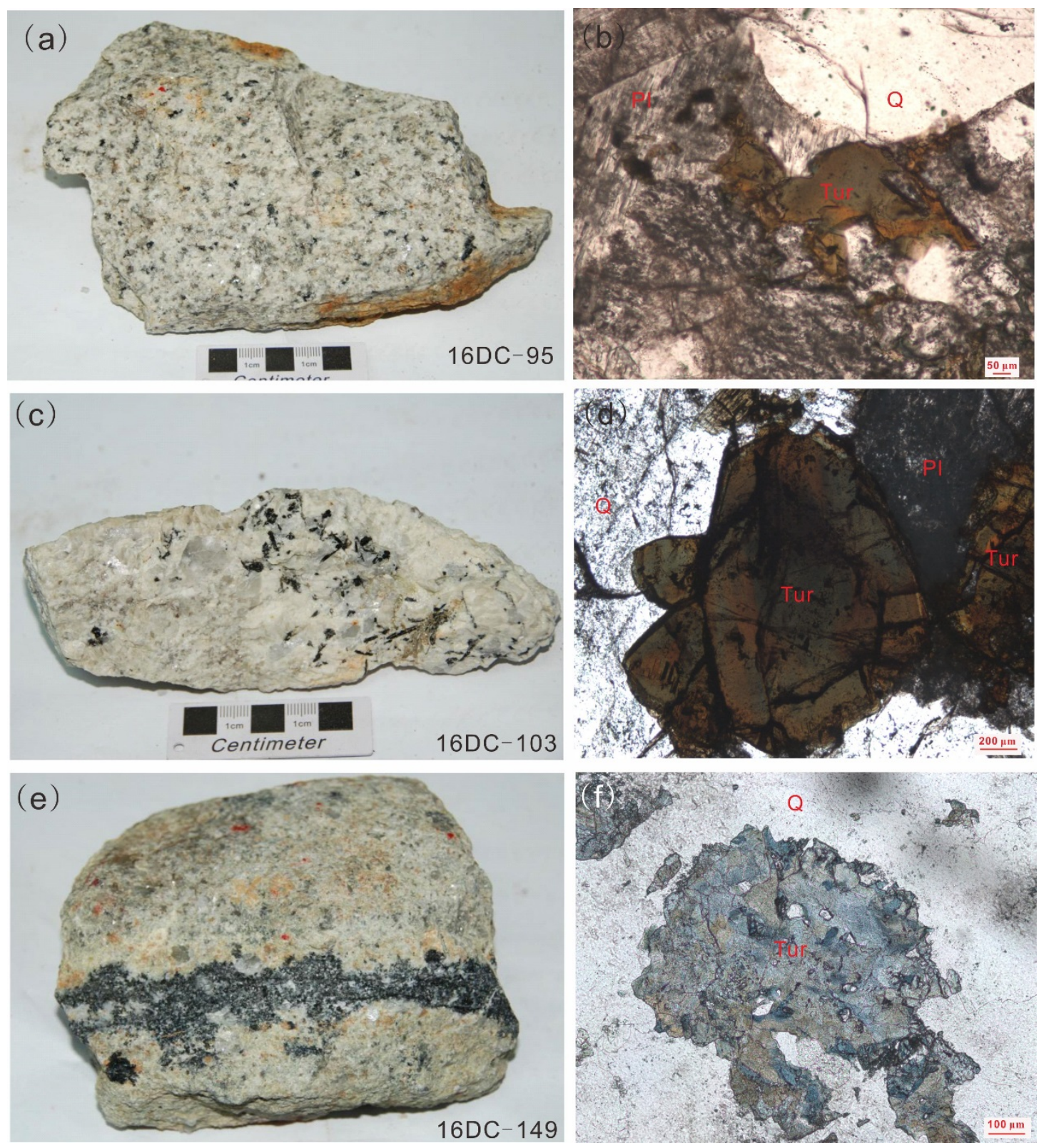
Figure 7.
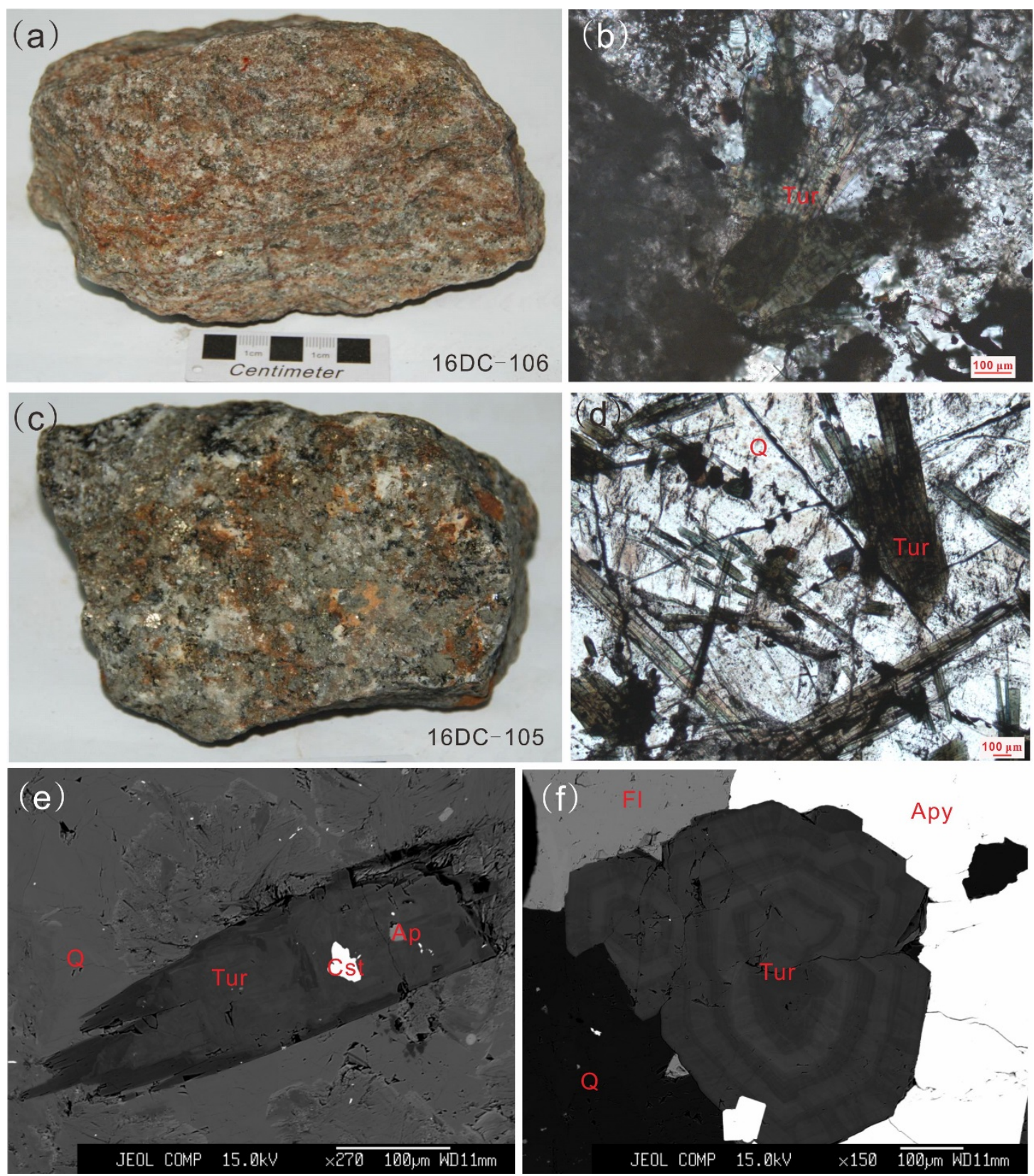
Figure 8.
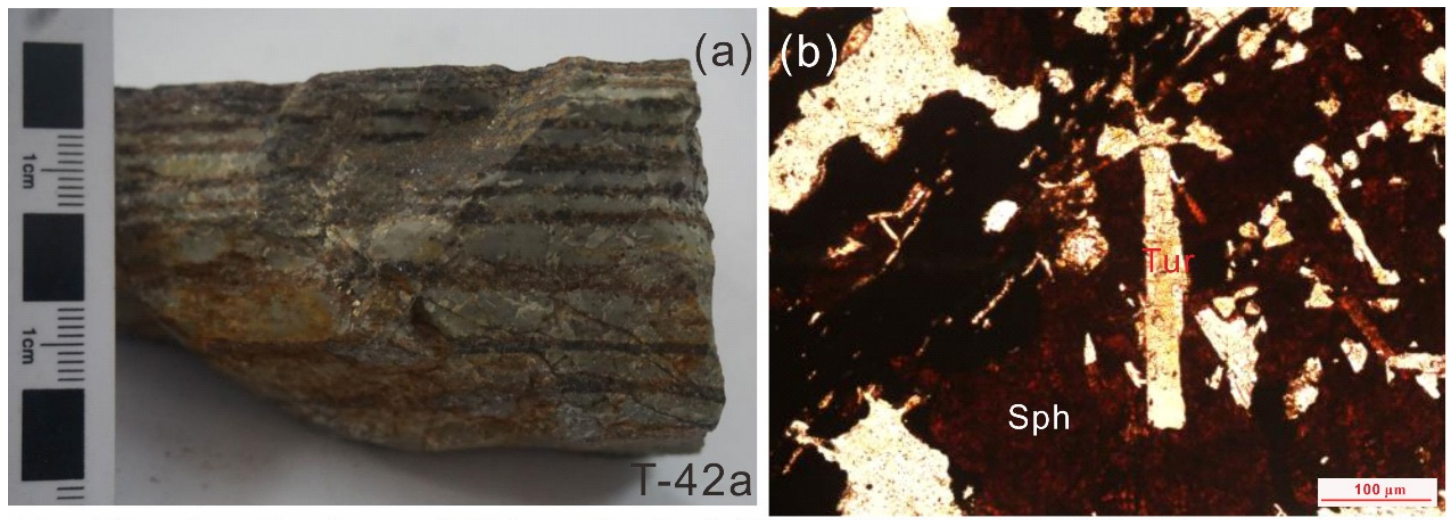

(c) $(1 ;-1)$
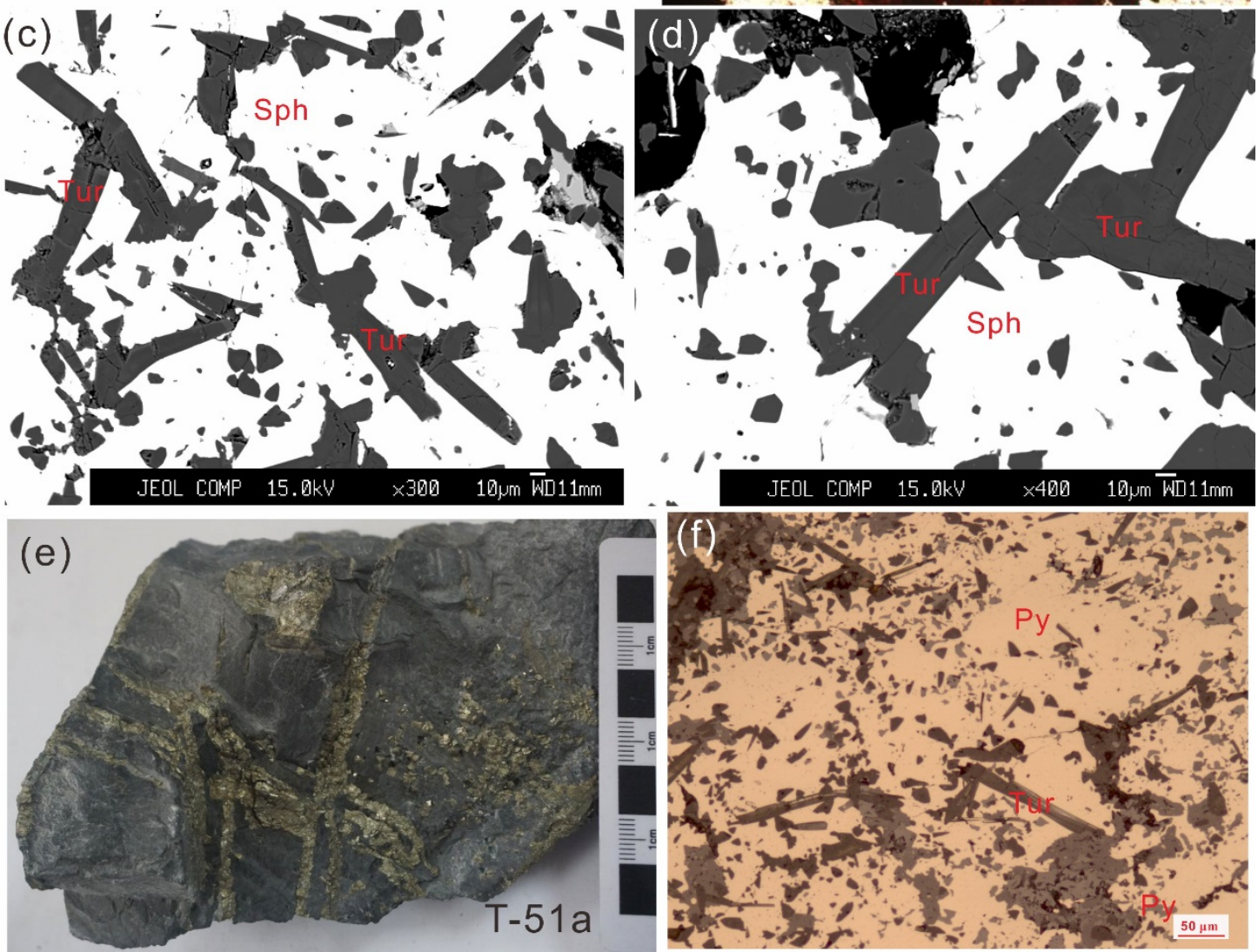
Figure 9.

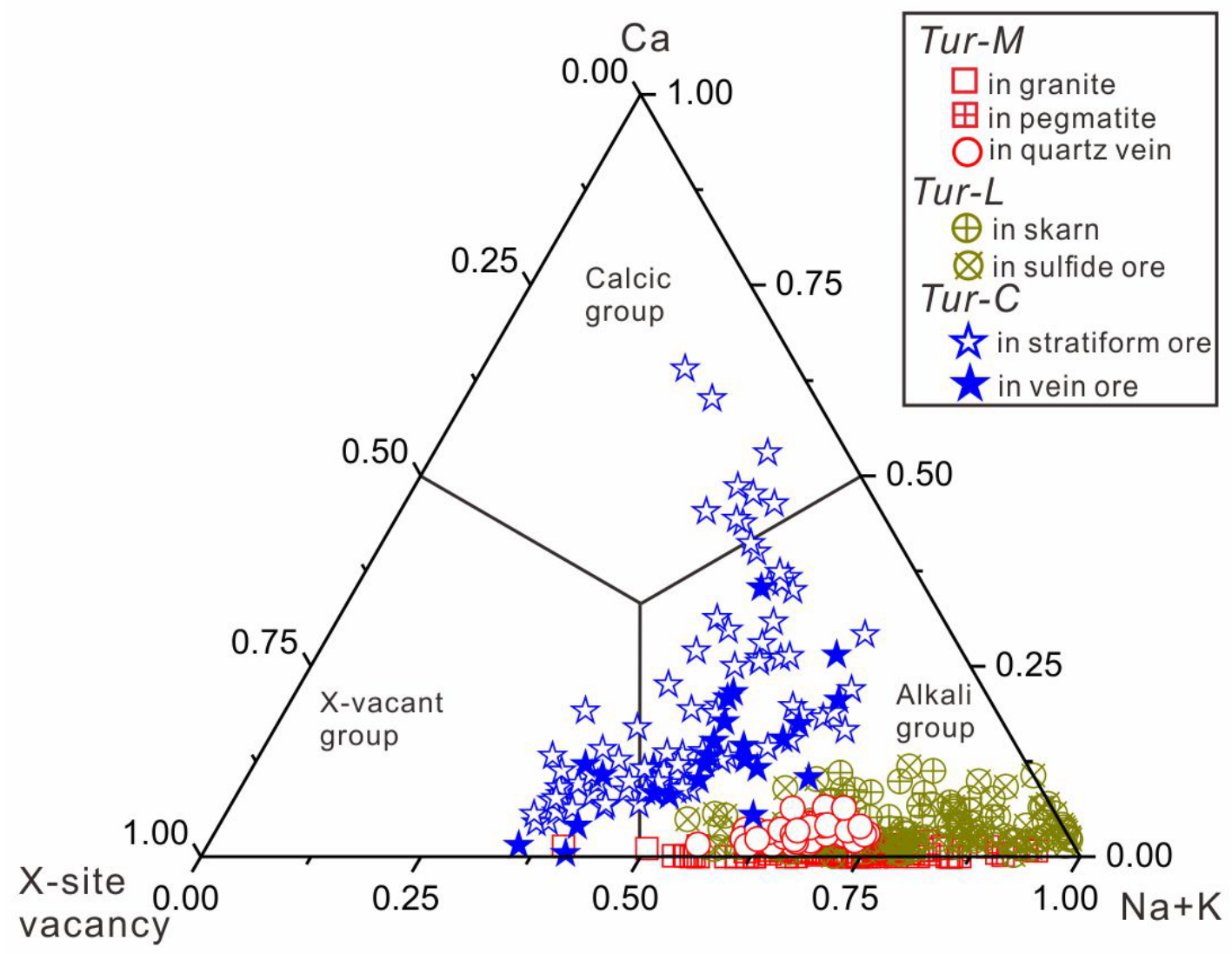


Figure 10.
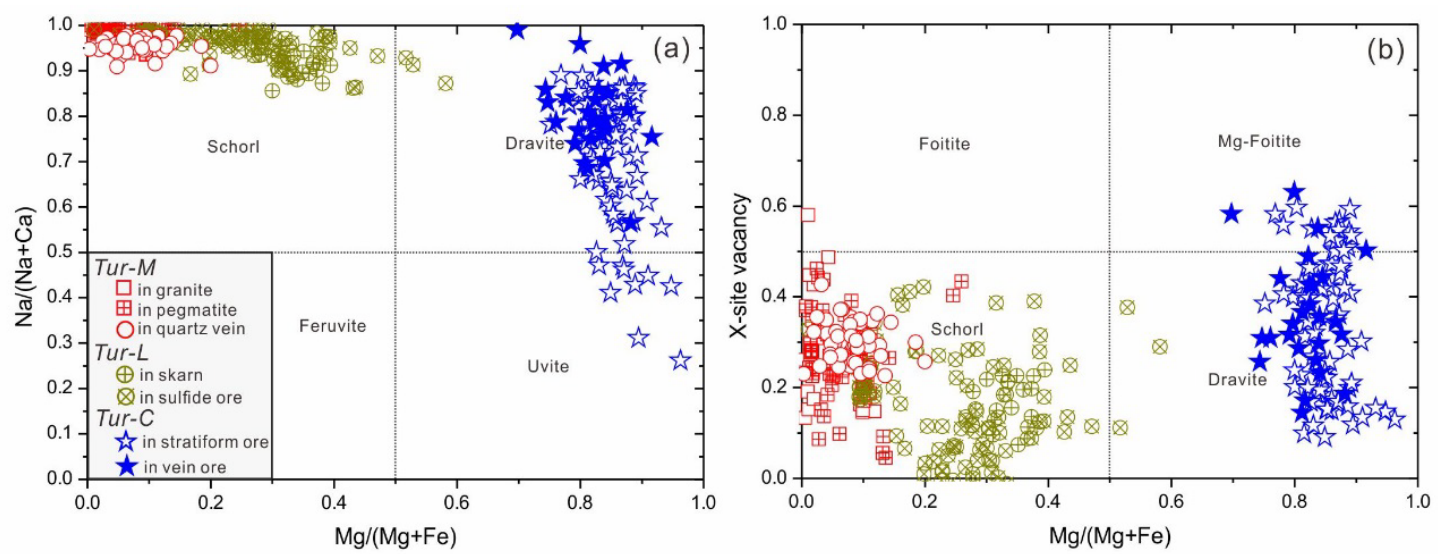
Figure 11.

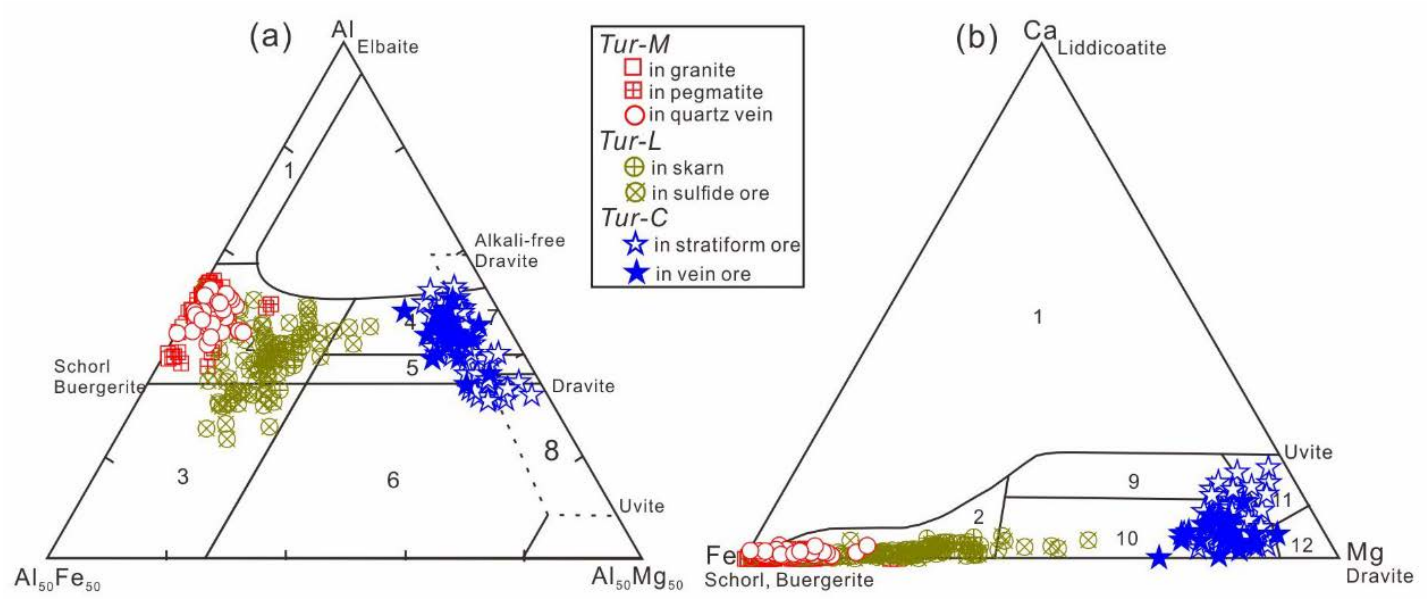


Figure 12.
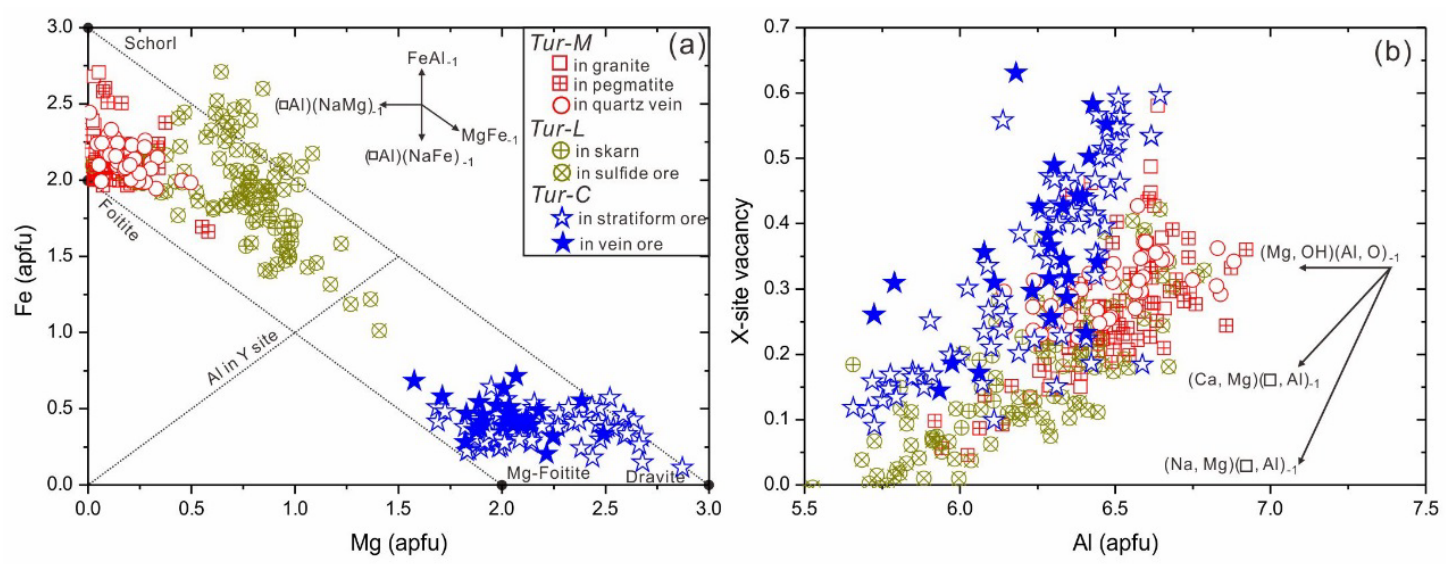
Figure 13.
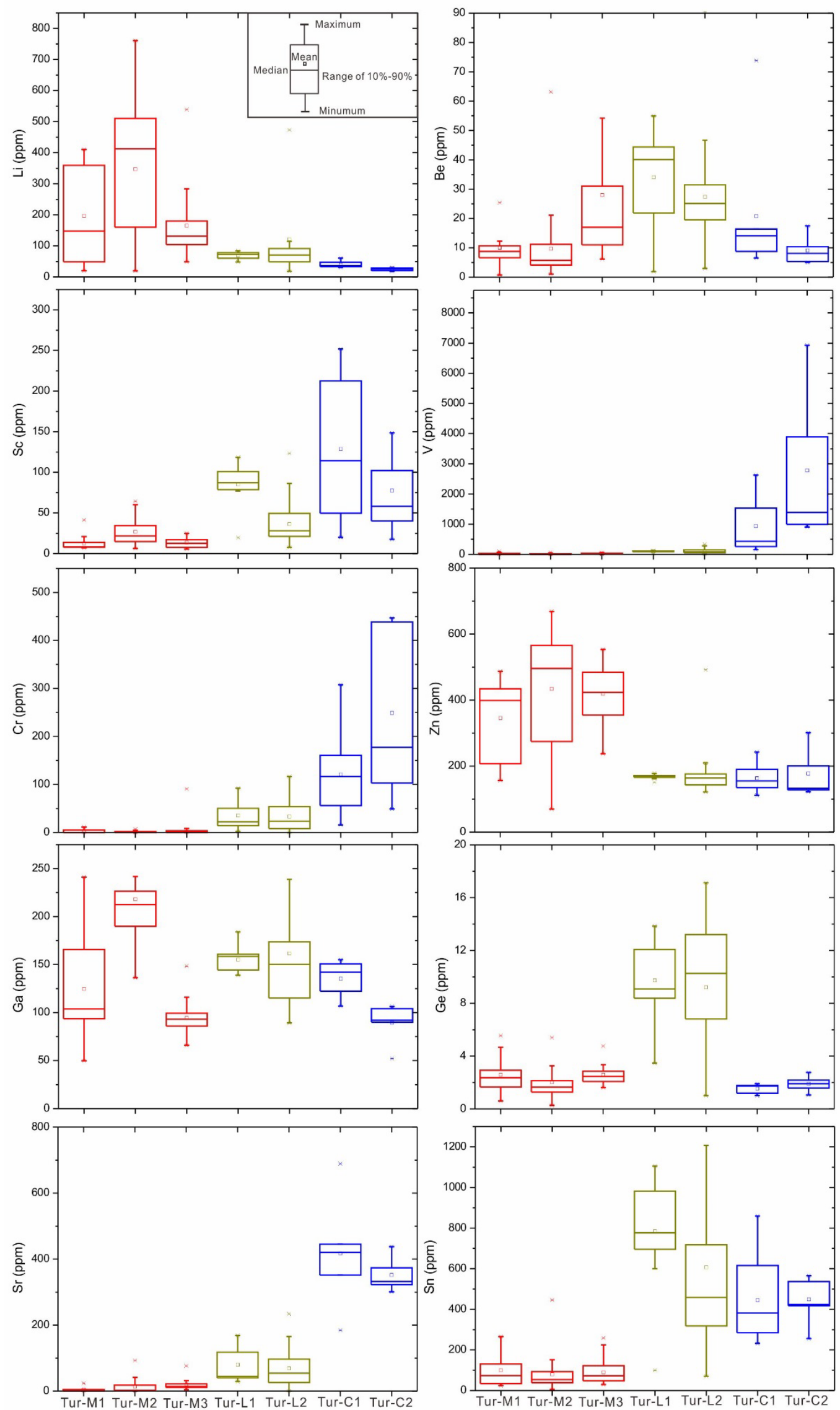
Figure 14.
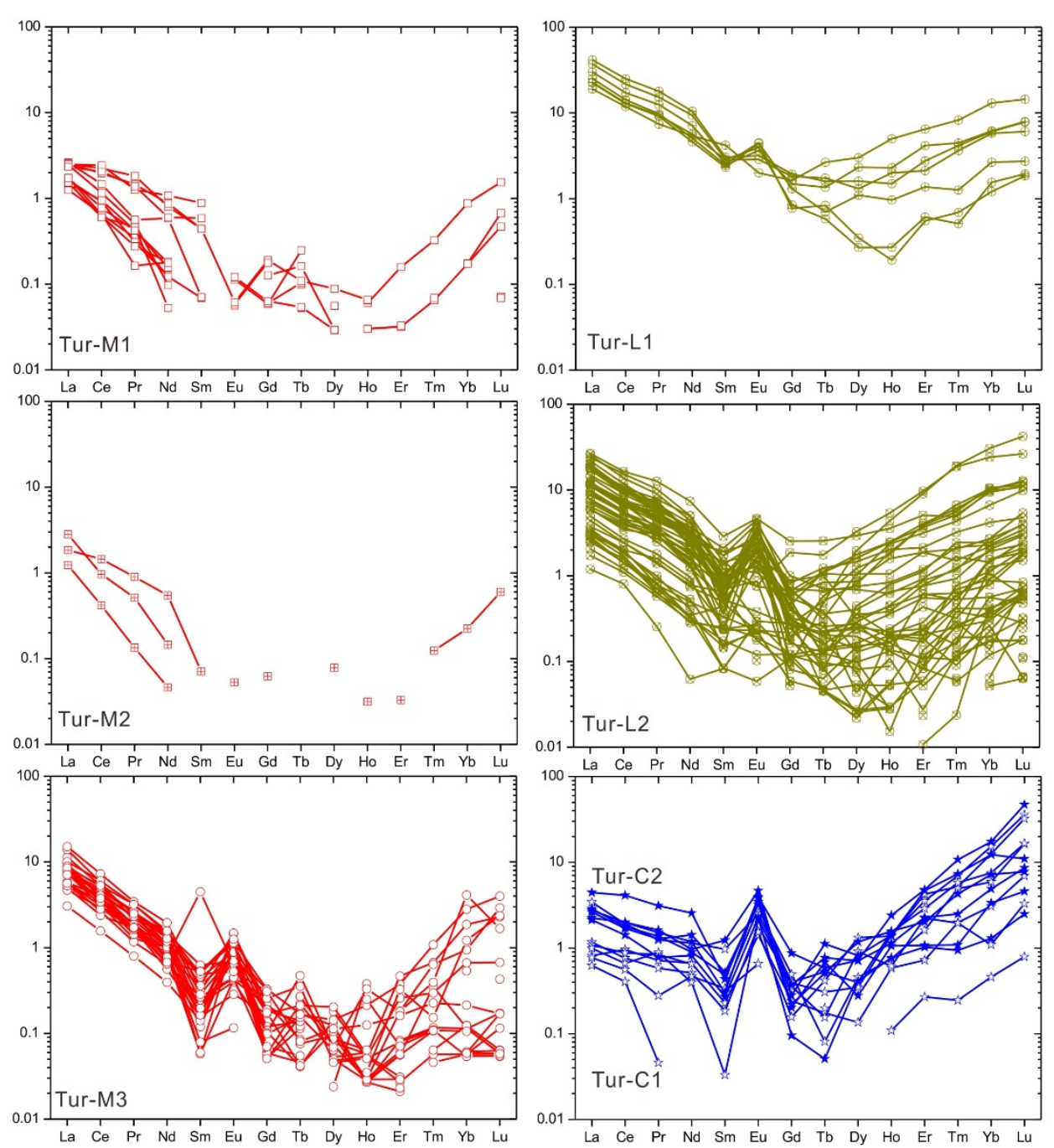
Figure 15.
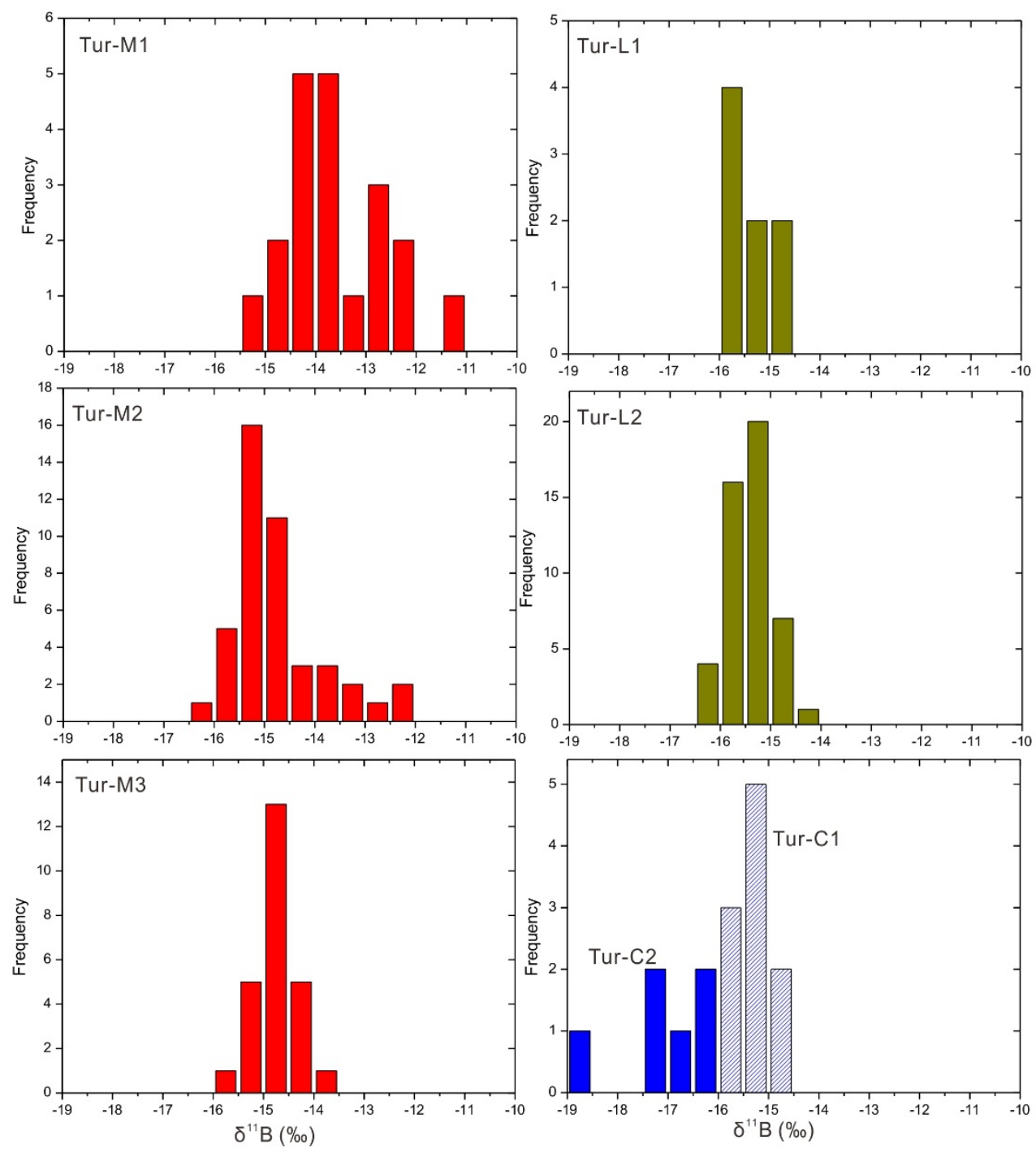
Figure 16.
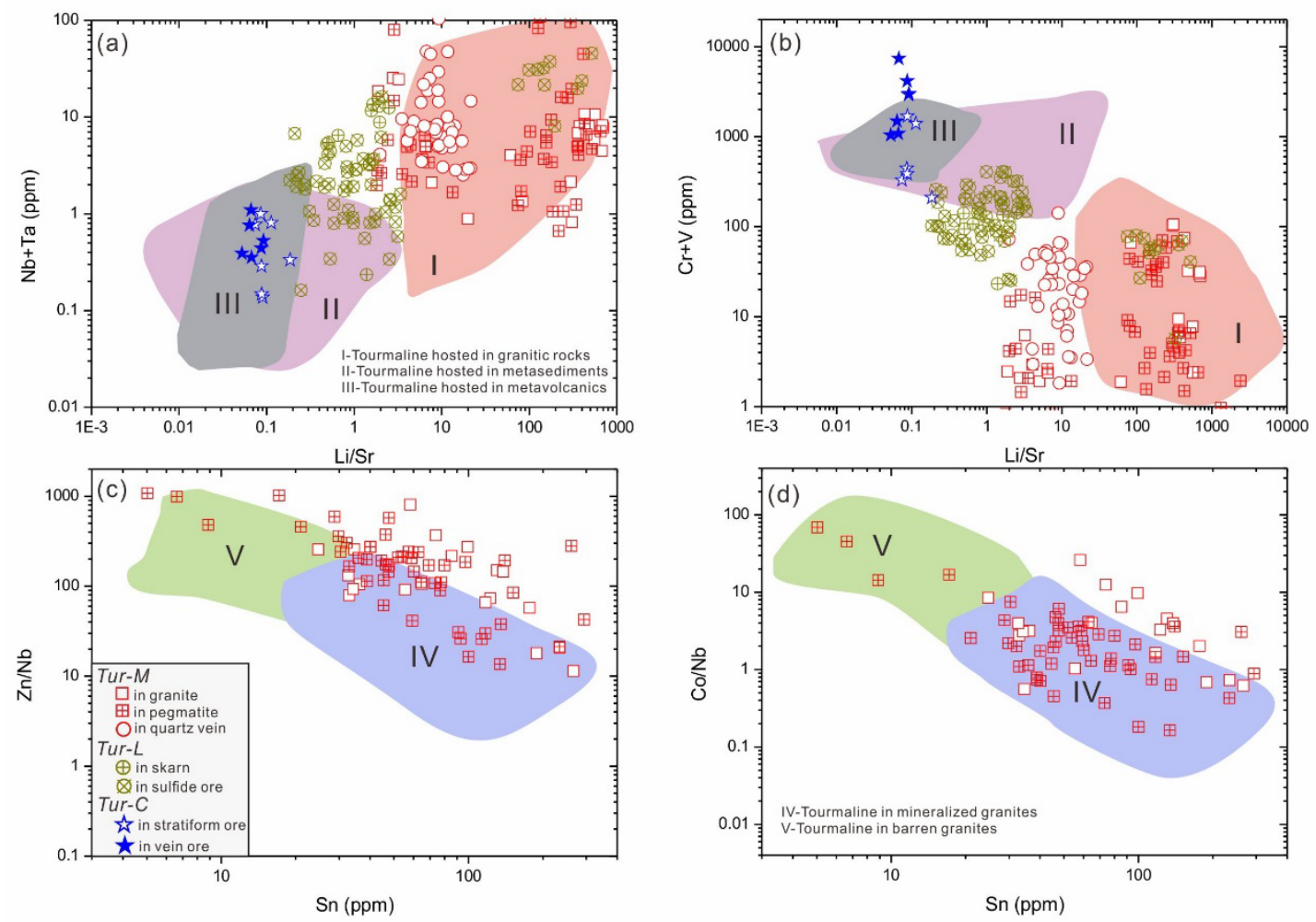
Figure 17.

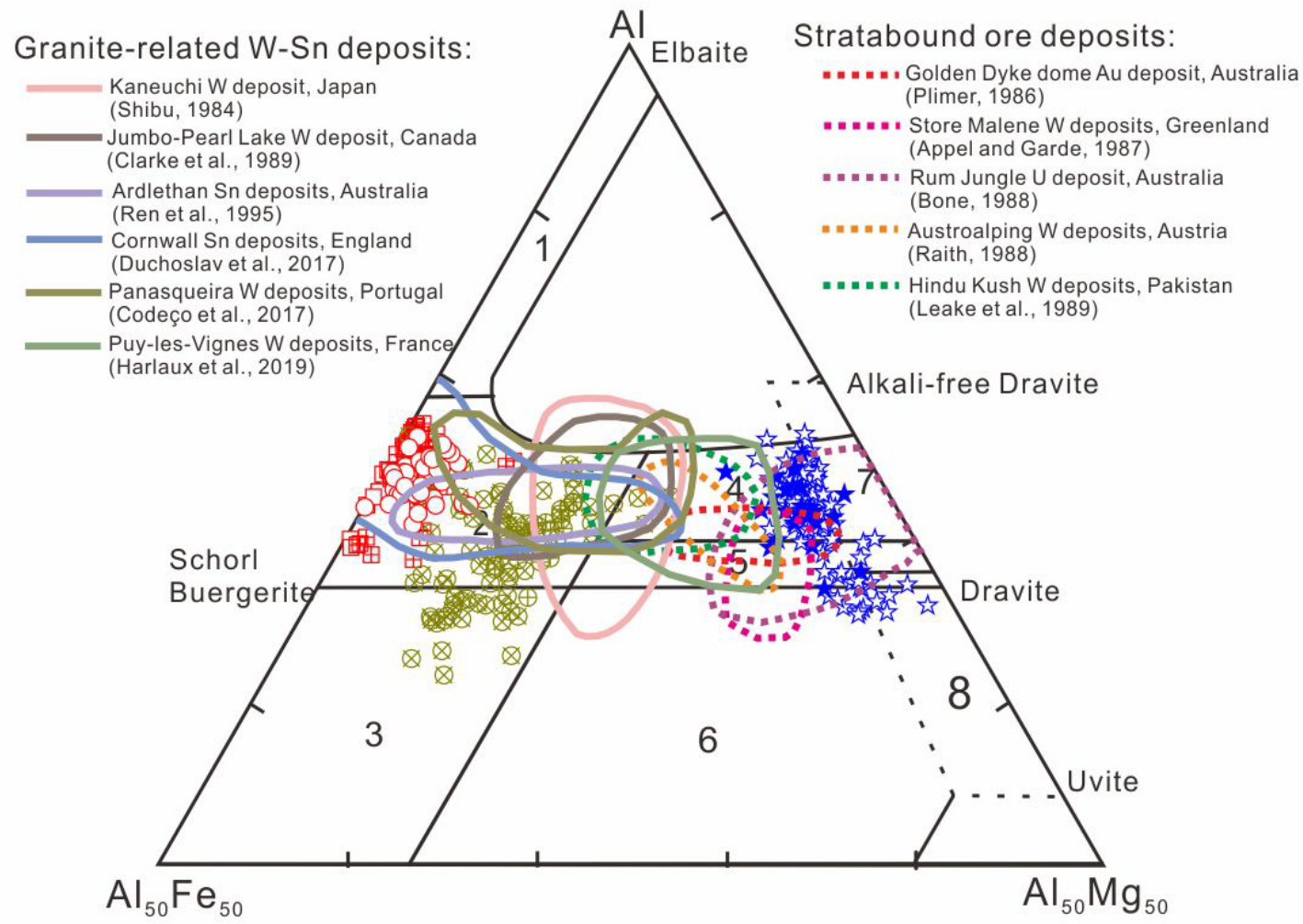


Table 1. Ore reserves, host rocks, and mineral associations of main orebodies at the Dachang district

\begin{tabular}{|c|c|c|c|c|c|}
\hline Ore deposit & Orebodies & Reserves & Occurrence & Host rocks & Mineral association \\
\hline Lamo & & $\begin{array}{l}10 \mathrm{Mt}, 2 \% \mathrm{Cu}, 5 \% \mathrm{Zn}, \\
<0.1 \% \mathrm{Sn}\end{array}$ & $\begin{array}{l}\text { Chimneys, manto, } \\
\text { pods }\end{array}$ & Skarn & $\begin{array}{l}\mathrm{Py}+\mathrm{Po}+\mathrm{Ccp}+\mathrm{Sp}+\mathrm{Grt}+\mathrm{Di}+\mathrm{Adr}+\mathrm{Ep}+\mathrm{Wo}+ \\
\mathrm{Fl}\end{array}$ \\
\hline Changpo- & 91 & 50 Mt, 4\% Zn, $1.3 \%$ Sn & Stratiform & Limestone & $\mathrm{Po}+\mathrm{Sp}+\mathrm{Apy}+\mathrm{Py}+\mathrm{Cst}+\mathrm{Jms}+\mathrm{Qz}+\mathrm{Tur}$ \\
\hline \multirow[t]{3}{*}{ Tongkeng } & 92 & $\begin{array}{l}25 \mathrm{Mt}, 2.1 \% \mathrm{Zn}, 0.8 \% \\
\text { Sn }\end{array}$ & Stratiform & Siliceous rock & $\mathrm{Po}+\mathrm{Sp}+\mathrm{Apy}+\mathrm{Py}+\mathrm{Cst}+\mathrm{Jms}+\mathrm{Qz}+\mathrm{Tur}$ \\
\hline & Vein & 5 Mt, 7.4\% Zn, 2.0\% Sn & Vein & Limestone & $\mathrm{Py}+\mathrm{Sp}+\mathrm{Cst}+\mathrm{Apy}+\mathrm{Jms}+\mathrm{Qz}+\mathrm{Tur}$ \\
\hline & Stockwork & $6 \mathrm{Mt}, 2.7 \% \mathrm{Zn}, 0.6 \% \mathrm{Sn}$ & Stockwork & Limestone & $\mathrm{Py}+\mathrm{Sp}+\mathrm{Cst}+\mathrm{Apy}+\mathrm{Jms}+\mathrm{Qz}+\mathrm{Tur}$ \\
\hline Gaofeng & 100,105 & $\begin{array}{l}\text { 10Mt, } 9.7 \% \mathrm{Zn}, 1.86 \% \\
\text { Sn, } 4.84 \% \mathrm{~Pb}, 4.22 \% \\
\text { Sb, } 148 \text { ppm Ag }\end{array}$ & Massive & Reef carbonate & $\begin{array}{l}\mathrm{Py}+\mathrm{Sp}+\mathrm{Apy}+\mathrm{Gn}+\mathrm{Po}+\mathrm{Jms}+\mathrm{Cst}+\mathrm{Qz}+\mathrm{Cal}+ \\
\mathrm{Adr}\end{array}$ \\
\hline Dafulou & $0,21,22$ & $4 \mathrm{Mt}, 1.1 \% \mathrm{Sn}, 0.3 \% \mathrm{Zn}$ & $\begin{array}{l}\text { Stockwork, } \\
\text { stratabound }\end{array}$ & Black shale & $\mathrm{Cst}+\mathrm{Apy}+\mathrm{Po}+\mathrm{Sp}+\mathrm{Qz}+\mathrm{Cal}$ \\
\hline Huile & & $1 \mathrm{Mt}, 1.1 \% \mathrm{Sn}, 1.0 \% \mathrm{Zn}$ & Vein, stratabound & Black shale & $\mathrm{Cst}+\mathrm{Po}+\mathrm{Sp}+\mathrm{Cal}+\mathrm{Qz}$ \\
\hline Kangma & & $1 \mathrm{Mt}, 0.5 \% \mathrm{Sn}$ & Sheeted vein & Black shale & $\mathrm{Cst}+\mathrm{Po}+\mathrm{Sp}+\mathrm{Qz}$ \\
\hline
\end{tabular}

Py pyrite, Po pyrrhotite, Ccp chalcopyrite, Sp sphalerite, Apy arsenopyrite, Cst cassiterite, Jms jamesonite, Gn galena, Grt garnet, Di diopside, Adr andradite, Ep epidote, Wo wollastonite, $Q z$ quartz, Cal calcite, Fl fluorite, Tur tourmaline 